Ethiopian Journal of Environmental Studies \& Management 10(3): 315 - 339, 2017.

ISSN: 1998-0507

doi: https://dx.doi.org/10.4314/ejesm.v10i3.4

Submitted: December 10, 2016

Accepted: April 08, 2017

\title{
SEDIMENT INFLOW ESTIMATION AND MAPPING ITS SPATIAL DISTRIBUTION AT SUB-BASIN SCALE: THE CASE OF TENDAHO DAM, AFAR REGIONAL STATE, ETHIOPIA
}

\author{
ASMELASH TILAHUN, ${ }^{1}{ }^{*}$ HAILE AREFAYNE SHISHAYE ${ }^{1}$ AND BOGALE \\ GEBREMARIAM $^{2}$ \\ ${ }^{1}$ School of Water Resource and Environmental Engineering, Institute of Technology, \\ Haramaya University, Dire Dawa, Ethiopia \\ ${ }^{2}$ Arbaminch University, Ethiopia
}

\begin{abstract}
Sedimentation is a major problem of reservoir operation in Ethiopia. Deforestation, overgrazing and poor land management practices are some that accelerate the rate of erosion. The topography of Ethiopia in general and TDW in particular is undulating and local farmers commonly cultivate on the hilly sides causing easy topsoil wash away. This study aims to determine the sediment yield at Tendaho dam reservoir, identify the high sediment source sub-basins and check the applicability of SWAT model in the area. To achieve these goals, the hydro-meteorological, sediment, topographic, land use and soil map data were used as inputs for the model. The model was successfully calibrated and validated for measured stream flow and sediment yield of AR at Wonji, Melka Werer and Tendaho stations. It was thus found applicable in this watershed with acceptable performance evaluation statistics values. From the model simulated output, sub-basins $27,34,29$ and 50 were found to be the top four severely eroded sub-basins with average annual sediment yield of $26.66 \mathrm{t} / \mathrm{ha}, 24.22 \mathrm{t} / \mathrm{ha}, 23.79 \mathrm{t} / \mathrm{ha}$ and $19.13 \mathrm{t} / \mathrm{ha}$, respectively. While, sub-basins 31, 18 and 21 were found to be the least sediment sources with annual averaged sediment yield of $0.02 \mathrm{t} / \mathrm{ha}, 0.04 \mathrm{t} / \mathrm{ha}$ and $0.04 \mathrm{t} / \mathrm{ha}$, respectively. In general, the results found in this study are very important inputs in selecting appropriate watershed management strategies and the methodologies used can also be valuable guides for the researchers in similar studies.
\end{abstract}

Key Words: SWAT Model; Sediment yield modeling; Sub-basins; Tendaho reservoir

\section{Introduction}

Erosion and deposition processes and sediment transportation along streams and rivers are rules, not exceptions. Despite of most natural river reaches are approximately balanced with respect to sediment inflow and outflow, dam construction dramatically alters this balance, creating an impounded river reach characterized by extremely low flow velocities and efficient sediment trapping. The impounded reach will accumulate sediment and loose storage capacity until a balance is again achieved,

*Corresponding Author: Haile Arefyne,

Email: haile.4.hiwot@gmail.com 
which would normally occur after the impoundment has become "filled up" with sediment and can no longer provide water storage and other benefits. Declining storage reduces and eventually eliminates the capacity for flow regulation (Morris et al., 1998).

Sedimentation can affect reservoir yield in three ways: it reduces conservation pool volume, sediment management may require that reservoir operation be altered, and watershed management for sediment control may affect water yield. The first two impacts can be readily evaluated within the framework of behavior analysis modeling, while the third requires modeling of watershed processes (Morris et al., 1998).

During the dam design phase, thorough investigation of the reservoir watershed regarding the parameters, such as, nature of the soil, intensive use of land for agriculture, pastures, systematic de-forestation, intensity of rainfall etc., should be carried out and documented (Alam, 2004). Therefore, based on the preliminary findings during the dam design stage it may either be concluded that the sediment yield from the watershed is compatible in regard to the long-term reservoir sedimentation rates and the project life or that in order to assure a reasonable project life, it might be possible to create appropriate vegetal cover which will reduce the watershed erosion characteristics. But, these findings may get changed after a period of time (Alam, 2004).

Tendaho dam is constructed for the purpose of irrigating nearly 60,000 ha sugarcane plantation with $1860 \mathrm{Bm}^{3}$ storage capacity. The total areal coverage of the water was expected to be about 17,000 ha (WWDSE and WPCS, 2005). But, at this time, Tendaho dam is at a risk of sedimentation and its storage capacity is declining, where the sediment source areas are not well identified for mitigation measures. Therefore, the objective of this study was to estimate sediment yield into Tendaho dam and its spatial variability at sub-basin scale.

\section{Material and Methods}

\section{Description of the Study Area}

Tendaho Dam, which is an earthfilled dam in the eastern Afar Region of Ethiopia, located at $11^{\circ} 41^{\prime} 29^{\prime \prime} \mathrm{N}$ and $40^{\circ} 57^{\prime} 17^{\prime \prime} \mathrm{E}$ is one of the working national projects in the Awash basin (AR). The watershed of the dam has a total area of $62,983 \mathrm{~km}^{2}$ (Fig. 2.1). Though, AR flow is the main flow on which the reservoir is dependent, it also receives flow from the Mille River. 

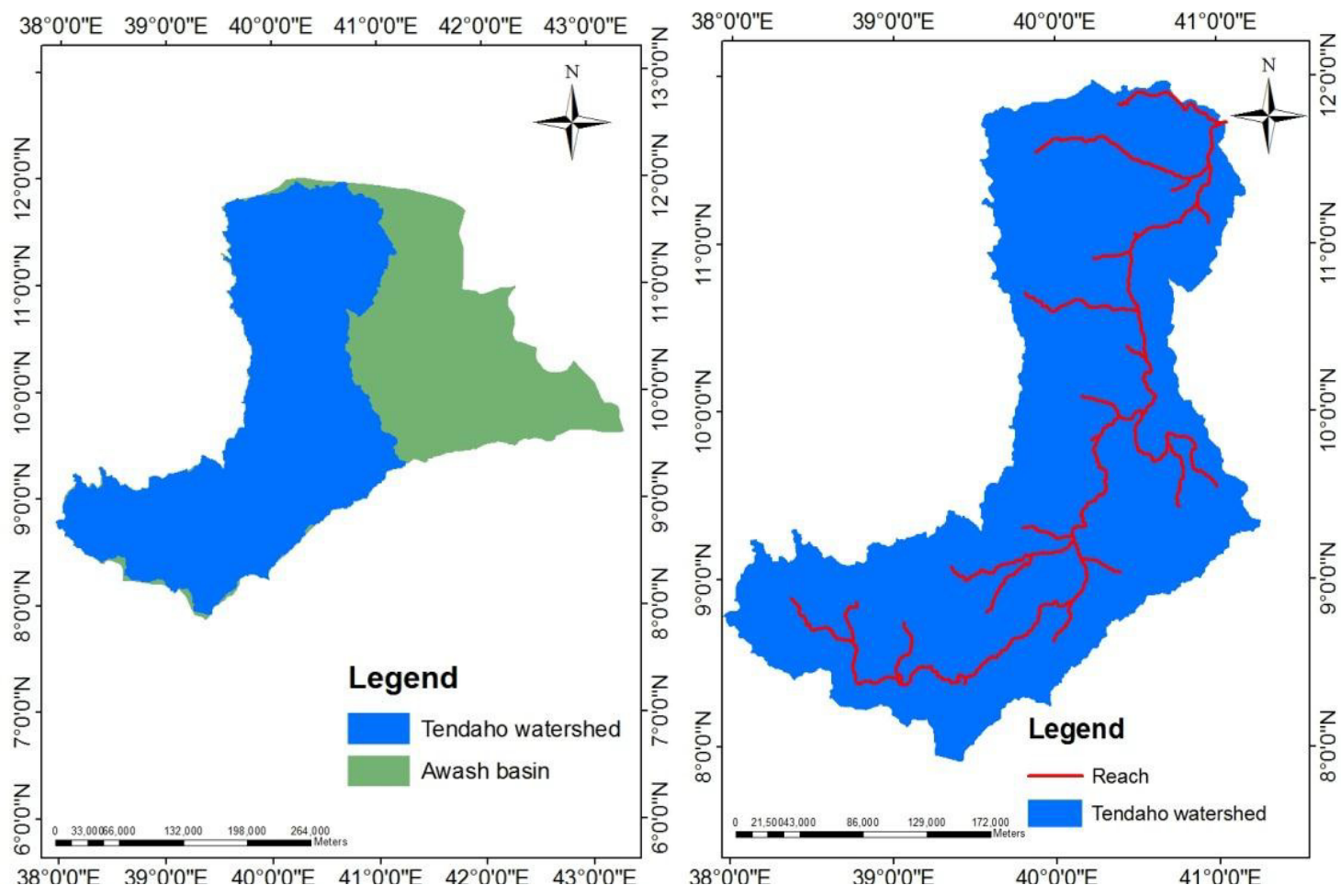

Figure 2.1: Location map of Tendaho dam watershed (TDW)

\section{Climate}

The mean annual rainfall distribution of TDW varies from $1174.15 \mathrm{~mm}$ to $521.78 \mathrm{~mm}$. Furthermore, its mean annual temperature ranges from $28.82{ }^{\circ} \mathrm{C}$ to $6.27{ }^{\circ} \mathrm{C}$ (Fig. 2.2). The rainfall distribution of the watershed on the base line of $(1990-2013)$ shows that high rainfall was occurred from July to September and low rainy season from March to May (Fig. 2.3).

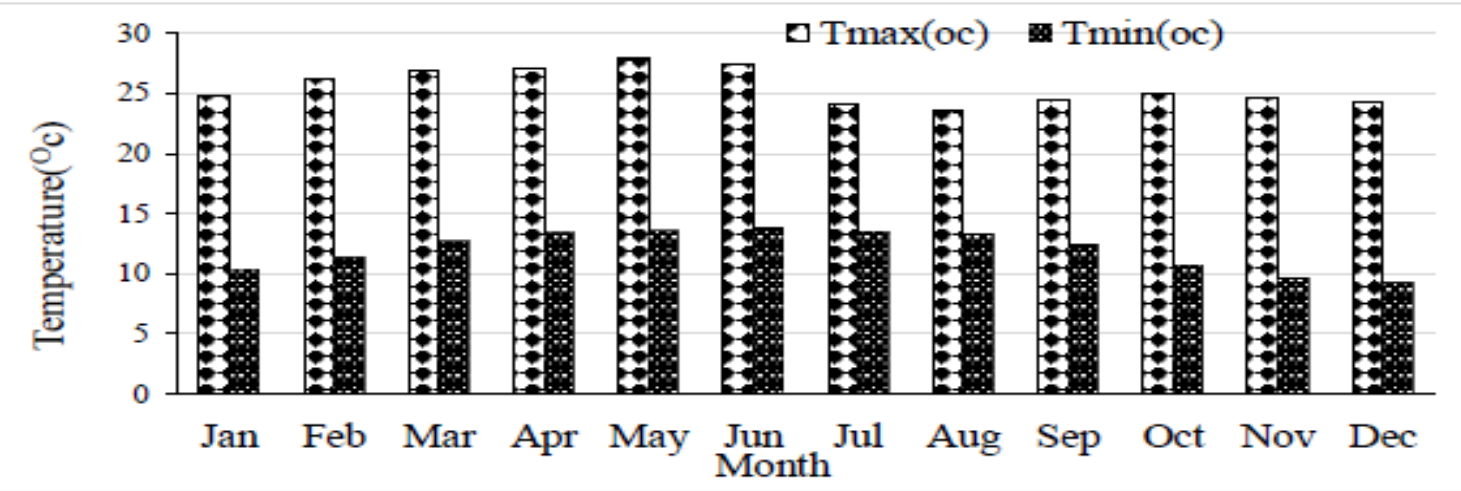

Figure 2.2: Mean monthly minimum and maximum temperature of TDW $(1990$ - 2013). 


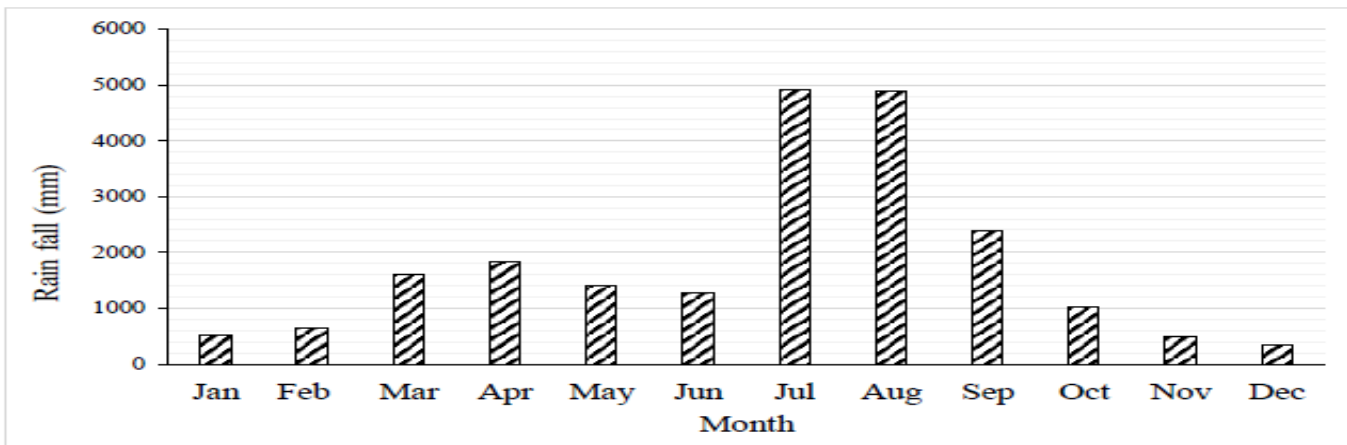

Figure 2.3: Mean monthly rainfall distribution of TDW (1990 - 2013)

\section{Water Resources Potential}

The AR rises on the high plateau to the West of Addis Ababa, at an altitude of about 3,000 m. It then flows Eastwards through the Becho Plains and is joined by several small tributaries before entering to Koka dam, commissioned in 1960. The total catchment area of the Koka reservoir is about $20,882 \mathrm{~km}^{2}$.

The mean annual runoff into Koka reservoir accounts around $1,660 \mathrm{Mm}^{3}$. About $90 \%$ of this runoff occurs in the period from July to October. It decreases to $1,390 \mathrm{Mm}^{3}$ at Awash station being depleted largely by losses from Koka and upper valley irrigation diversions. The mean annual flow is around $2,200 \mathrm{Mm}^{3}$ at Tendaho. Currently, $75 \%-80 \%$ of the mean annual runoff in Tendaho arrives during the period ranges from March to May and July to October.

\section{Soil of the Study Area}

Soils that exist dominantly in the watershed are Eutric regoslos, Eutric cambisols, pellic vertisols, orthic solonchaks, vertic cambisols, leptosols and vitric andosols (Fig. 2.5). Andosols have a high potential for agricultural activity, because of their fertility, ease of cultivation and root penetration. In Andosols dominant areas, the exposures to erosion are comparatively less; while, leptosols are easily erodible. Hence, severe erosion problems may be observed in Leptosols under high anthropogenic effects. Orthic solonchaks are characterized by high salt concentration and predominantly available in arid and semi-arid climate zones of the watershed (WWDSE and WPCS, 2005). The types of soils and their areal coverage (beyond $3.5 \%$ in the whole watershed) in the TDW are as shown below (Table 2.1).

Table 2.1: Soil types and area coverage in TDW

\begin{tabular}{lll}
\hline Soil type & Area coverage (ha) & \% area coverage over the whole watershed \\
\hline Chromic luvisols & 256341.6 & 4.07 \\
Eutric Cambisols & 822560.6 & 13.06 \\
Eutric regosols & 1032924 & 16.4 \\
Leptosols & 329402.1 & 5.23 \\
Orthic solonchaks & 652506 & 10.36 \\
Pellic Vertisols & 695334.5 & 11.04 \\
Vertic Cambisols & 539136.2 & 8.56 \\
Vertic andolsols & 260120.6 & 4.13 \\
\hline
\end{tabular}




\section{Land Use and Cover}

Presently, the natural vegetation of the watershed is highly disturbed anthropogenically. Grass, annual crop, shrub, bare soil and rock outcrop were identified as dominant land use/cover types. Their areal coverage on the watershed is outlined below (Table 2.2).

Table 2.2: Land use/cover type and area coverage in TDW

\begin{tabular}{lll}
\hline Land use/cover type & Area coverage (ha) & \% area coverage over the whole watershed \\
\hline Rock outcrop & 542285.352 & 8.61 \\
Bare soil & 729345.456 & 11.58 \\
Annual crop & 1417751.832 & 22.51 \\
Closed grasses & 1707474.552 & 27.11 \\
Open shrub & 810593.784 & 12.87 \\
\hline
\end{tabular}

\section{Conceptual Framework of the Study}

The methods and procedures used in this research to achieve the objectives are shown in Fig. 2.4.

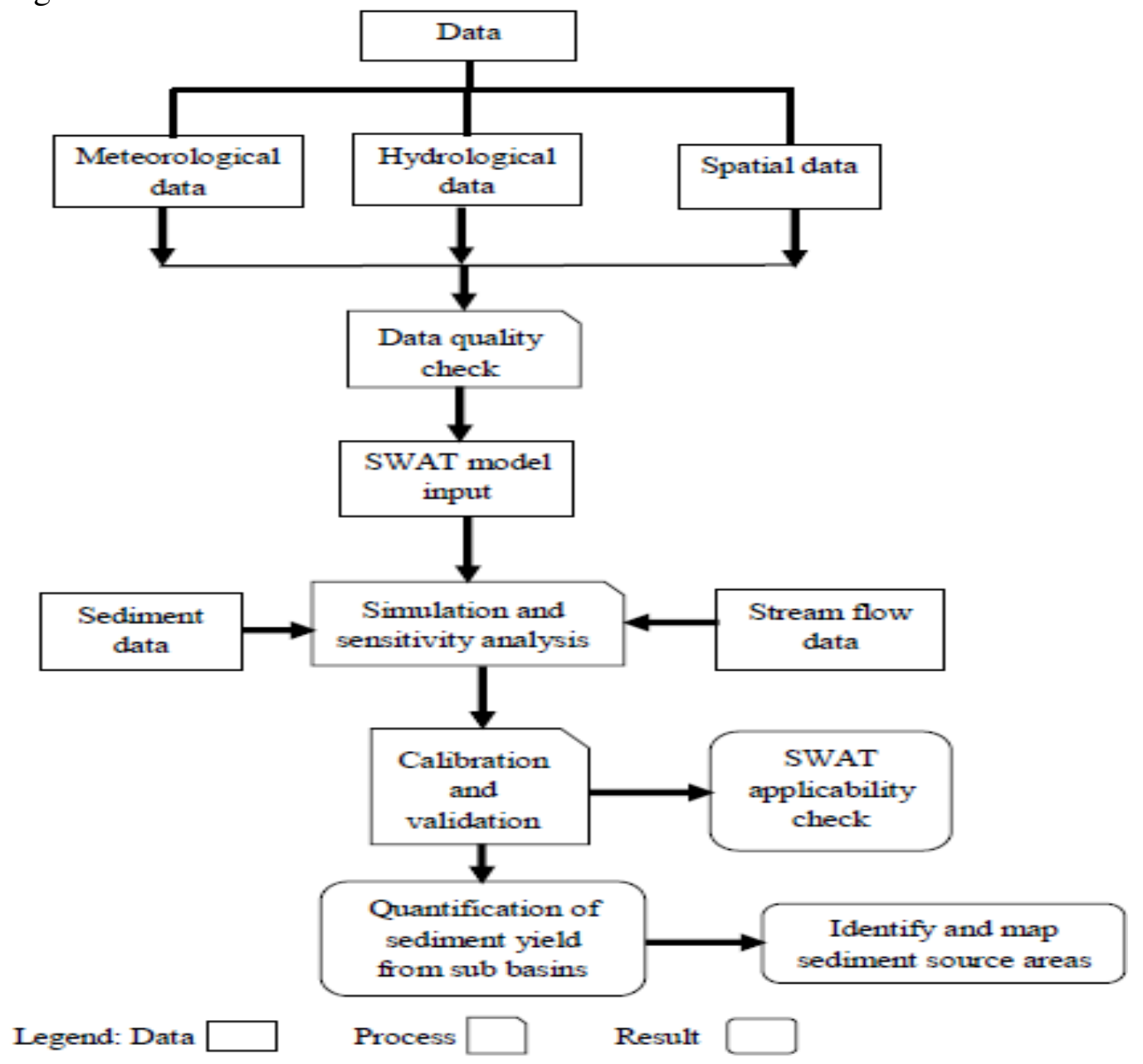

Figure 2.4: Conceptual frame work of the study 


\section{Soil Data}

SWAT model requires textural and physicochemical properties of the soil data such as available water content, hydraulic conductivity, texture, bulk density and organic carbon content of respective layers of soil type. These data were gathered mainly from AR Basin Integrated Development Master Plan project report. Accordingly, the soil map of the TDW is shown below (Fig. 2.5).
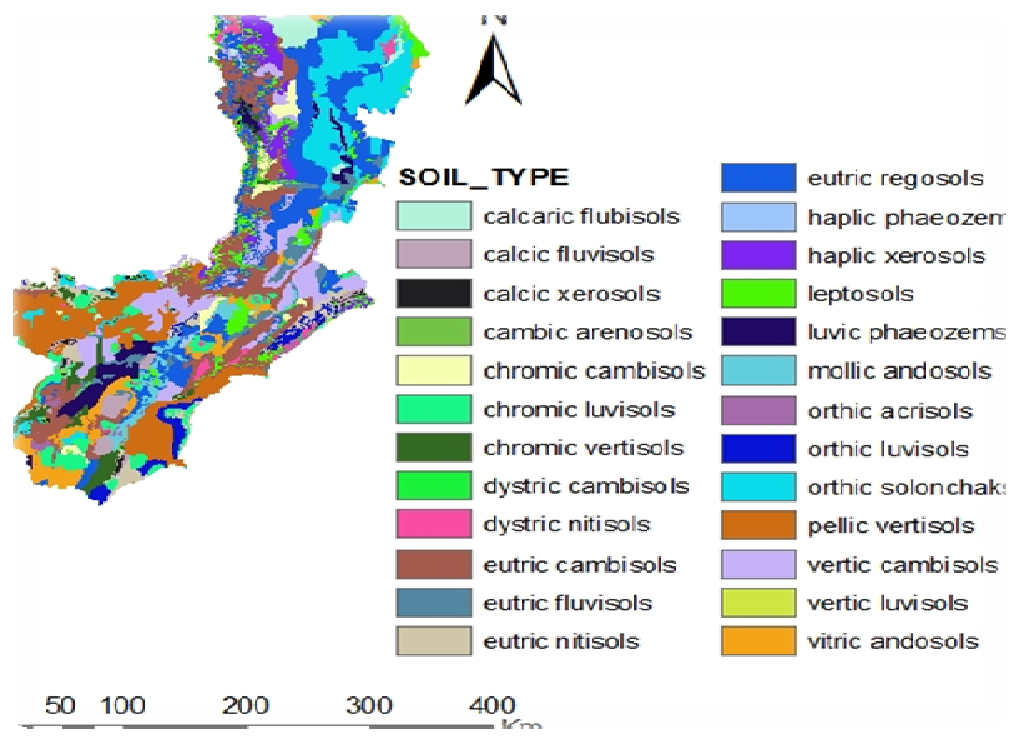

Figure 2.5: Soil map of Tendaho dam watershed

\section{Land Use}

Land use is one of the determinant factors for surface run-off, soil erosion and evapotranspiration in a watershed.
The land use for this study (land use, 2008) was obtained from Ethiopian ministry of Agriculture (EMoA) (Fig. 2.6).

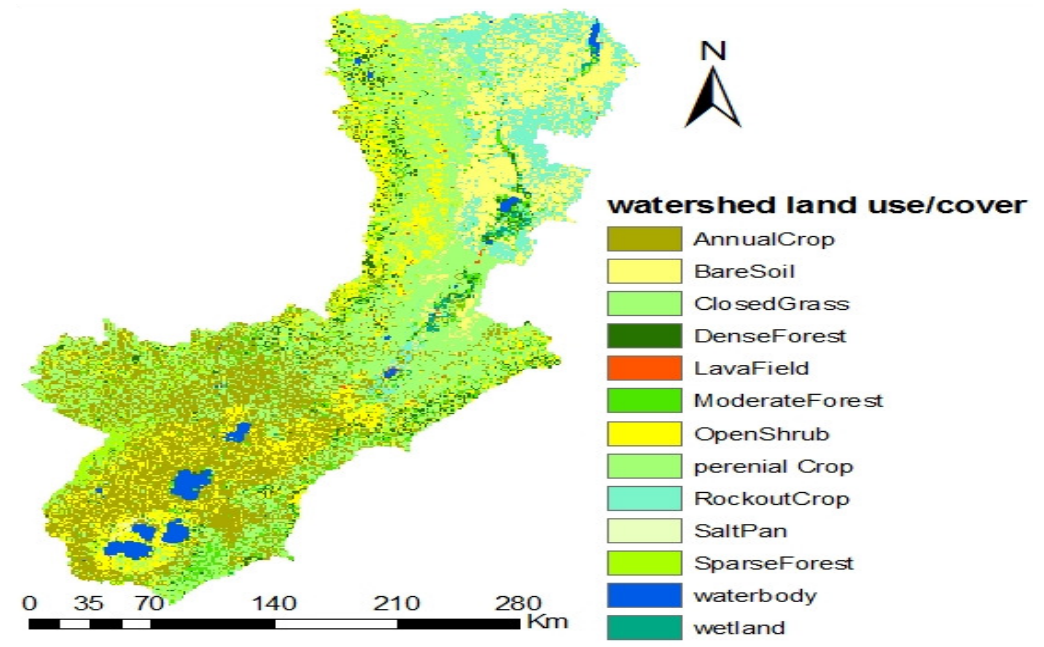

Figure 2.6: Land use/cover of TDW (EMoA, 2008) 


\section{Weather Data Definition and Weather Generator}

Weather data such as daily rainfall data, temperature, Wind speed, relative humidity and solar radiation were prepared according to the model input format requirements. The weather data used were represented from the nine selected stations (Abomsa, Bati, Kulumsa, Gewane, Debreberhan, Melkasa, Nazerete, Gelemso and Majet). Weather parameter values for the weather generator were developed using PCP stat and dew point temperature calculator, DEW02.

\section{River Discharge}

The selected stations of stream flow measurement of AR at Wonji, Melka Werer and Tendaho were obtained from Ethiopian Ministry of Water, Irrigation and Energy. The average monthly flow at these stations was used for SWAT model calibration and validation (Fig. 2.7).

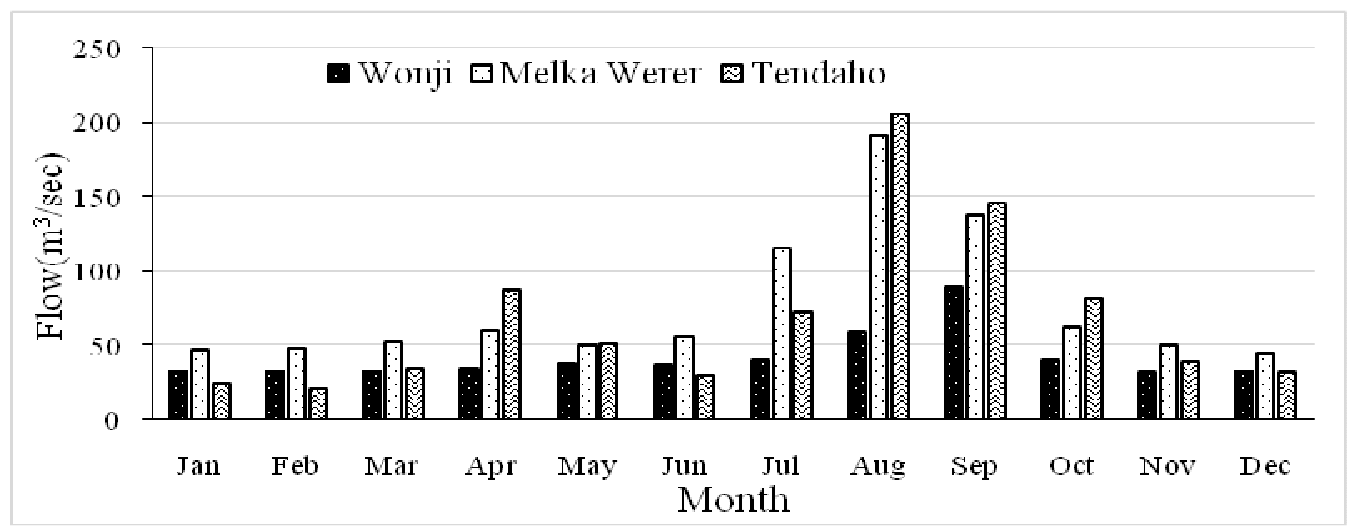

Figure 2.7: Mean monthly stream flow of the selected gauging stations $(2000-2010)$

\section{Data Analysis}

\section{Meteorological Data}

Daily data of precipitation, temperature (Max \& Min), sunshine hours, relative humidity and wind speed of all synoptic stations around and at the TDW were collected. But, most of these stations were almost null and the authors decided to select meteorological stations with relatively better data content. Nine meteorological stations were used for this study, where Abomsa and Bati stations $P_{x}=\frac{1}{N}\left(P_{A}+P_{B}+P_{C}+\cdots+P_{N}\right)-----------------2.1$

For more than $10 \%$ variation of the adjacent stations from the station in question, the normal ratio method was used (Equation 2.2).

$\boldsymbol{P}_{X}=\frac{1}{N}\left(\frac{N_{X}}{N_{A}} P_{A}+\frac{N_{X}}{N_{B}} P_{E}+\frac{N_{X}}{N_{C}} P_{C}+\cdots+\frac{N_{X}}{N_{N}} P_{N}\right)------------2.2$ were selected as weather generator stations, to generate for the missing data of the other stations.

\section{Filling Missing Rainfall Data}

Missing rainfall data were estimated from other stations nearby. Provided that the mean monthly rainfall of all the index stations is within $10 \%$ of the station under consideration, the simple arithmetic mean method was used to fill the missing data (Equation 2.1). 
Where, $P_{X}$ is the precipitation for the station with missed record, $P_{A}, P_{E}, P_{C}, \ldots P_{N}$ are the corresponding precipitation at the index stations, and $N_{A}, N_{E}, N_{C}, \ldots \ldots N_{N}$ and $N_{X}$ are the long-term mean monthly precipitations at the index stations and at station $X$, station under consideration, respectively.

\section{Homogeneity Test of the Selected Rainfall Stations}

The rainfall stations were tested for homogeneity with the help of the non-dimensional rainfall records method. The non-dimensional values of the monthly precipitation of each station were computed by:

$p_{i}=\frac{P i_{2} a v}{P a v}: 100----------------------2.3$

Where, $\boldsymbol{P} i$ is the non- dimensional value of precipitation for the month in station $\mathrm{i}, \mathrm{Pi}$, av is the over years averaged monthly precipitation for the station $\mathrm{i}$ and Pav is averaged yearly precipitation of the station $\mathrm{i}$.

\section{Consistency Check and Adjustment of Rainfall Stations}

Consistency of the rainfall data of the selected stations was checked by double mass curve. If significant change is observed in the curve, it can be corrected using Equation 2.4.

$$
P c x=P x * \frac{M c}{M e}----------------------2.4
$$

Where, $\mathrm{Pcx}=$ corrected precipitation at any time period, $\mathrm{Px}=$ original recorded precipitation at a time period, $\mathrm{Mc}=$ corrected slope of the double mass curve and $\mathrm{M}_{\mathrm{a}}=$ original slope of the double mass curve.

\section{Areal Rainfall Computation}

Thiessen polygon method was used due to its simplicity to use, and the average rainfall over the catchment was calculated by:

$P_{\text {cv }}=\frac{P_{1} A_{1}+P_{2} A_{2}+P_{3} A_{3}+\cdots+P_{n} A_{n}}{A_{1}+A_{2}+A_{3}+\cdots+A_{n}}-------------2.5$

Where, $P_{a v}$ is average areal rainfall $(\mathrm{mm}), P_{1}, P_{2}, P_{3} \ldots P_{n}$ are precipitation of stations 1,2 , 3 , n, respectively, and $A_{1}, A_{2}, A_{3}, \ldots A_{n}$ area coverage of stations $1,2,3, \ldots . \mathrm{n}$, respectively in the Thiessen polygon.

\section{Hydrological Data Analysis}

Filling of Missing Stream Flow Data

The TDW has a number of streams, where some of the streams have seasonal flow, while the focus of this study was on the flow of the main AR which flows throughout the year. The selected gauging stations of AR for this case were Awash at Wonji, Melka Werer and Tendaho, because these stations approximately represent the area of the watershed. Filling of the missing data was made in two divisions: for wet season using the linear regression between consecutive wet season months, and for dry season the recession curve method (Equation 2.6).

$Q_{t}=Q_{t_{0}} \exp \left(-\frac{t-t_{0}}{k}\right)-----------------2.6$

Where, $Q_{t}$ is the missed flow data $\left(\mathrm{m}^{3} / \mathrm{sec}\right)$ in day, $Q_{t_{g}}$ is a specified initial daily mean discharge $\left(\mathrm{m}^{3} / \mathrm{sec}\right), \mathrm{k}$ is the watershed characteristics and is the inverse of flow recession 
$(\alpha)$ or also called a reaction factor. K can be calculated by the slope of the logarithmically transformed flow series data values of the flow last before the gap at time $t_{o}\left(Q_{t_{0}}\right)$ and the first flow value after the gap at time $t_{1}\left(Q_{\varepsilon_{1}}\right)$ as follows.

$$
\frac{1}{k}=\alpha=\frac{\ln _{\mathrm{t}_{0}}-\ln _{\mathrm{t}_{1}}}{t_{\mathrm{1}}-t_{0}}---------------7.7
$$

\section{SWAT Model Setup and Inputs Watershed Delineation}

SWAT model allows users to delineate the watershed and partition into sub-basins depending on its Digital Elevation Model (DEM). The size and number of sub-basins and details of stream networks depend on the threshold area (Winchell et al., 2007). In this study, the threshold area was taken 60,000 ha and the watershed outlet was manually added and selected, and the model was ordered to consider the existence of a reservoir (Koka reservoir) to finalize the watershed delineation. Given these information, the model automatically delineated the watershed area of $62,983 \mathrm{Km}^{2}$ with 79 sub-basins.

\section{HRU Definition}

The HRU in the Arc-SWAT requires the land-use and soil maps to be loaded to the project and also classifies the slope of the sub-basins. Next to land use/cover loading, soil map was required to be loaded as per the SWAT format. Finally, defining the HRUs with in a sub-basin, HRU set up was completed. For this case study, the authors took $10 \%$ land use, $10 \%$ soil type and $10 \%$ slope as a threshold area, and 541 HRUs were created for the 79 sub-basins.

\section{Sensitivity Analysis}

Sensitivity analysis was ordered using a built-in tool in SWAT 2005, which uses the Latin Hypercube One-factor-At-aTime (LH-OAT) design method (Morris, 1991). As per (Lenhart et al., 2002), sensitive parameters were classified into four classes: $(0-0.05)$ small/negligible, $(0.05-0.2)$ medium, $(0.2-1.0)$ high, and $\geq 1$ very highly sensitive.

\section{Model Calibration and Validation}

The manual model calibration method, the most widely used method for large area modeling (Refsgaard and Storm, 1996), was used in this work. Calibration has taken place at the outlets of sub-basins 60 (Wonji), 37 (Melka Werer), and 2 (Tendaho). These sites were selected due to the variability in measured flow data and spatial distribution on the watershed. The stream flow and sediment calibration was on monthly time steps on the mentioned locations. The calibration was from upstream to downstream, without varying the calibrated parameter values on upstream. The period from Jan, 2000 Dec, 2001 was model "warm-up" period, and Jan, 2002 - Dec, 2006 was model calibration period, while validation was performed from Jan, 2007 - Dec, 2010. The statistical criteria $\left(\mathrm{R}^{2}, \mathrm{E}_{\mathrm{NS}}\right.$ and $\left.\mathrm{P}_{\mathrm{BIAS}}\right)$ were used in the validation procedure to make sure that the simulated result is within the accuracy limits.

\section{Result and Discussion}

\section{Sediment Rating Curve Preparation}

A sediment rating curve can be plotted showing an average sediment load as a function of discharge averaged over daily, monthly or other time periods. So, using rating curve, the records of discharges are transformed into records of sediment load and the general 
relationship can be formed. Then, using a continuous time step sediment load and been developed at the three selected measured stream flow a rating curve has

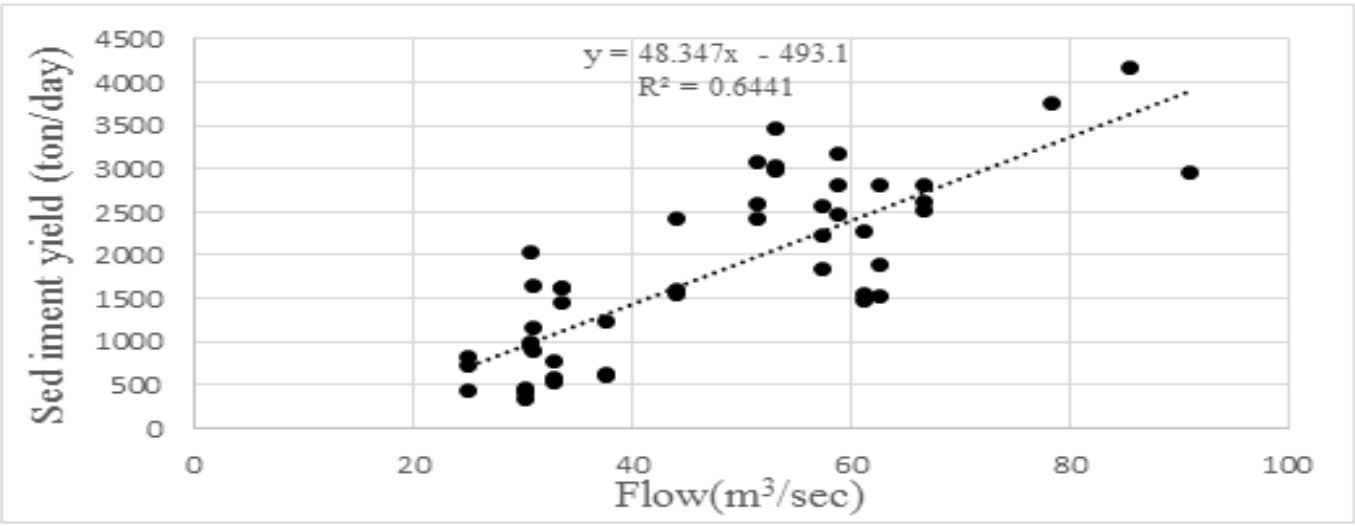

Figure 2.9: Sediment rating curve of AR at Wonji gauging station

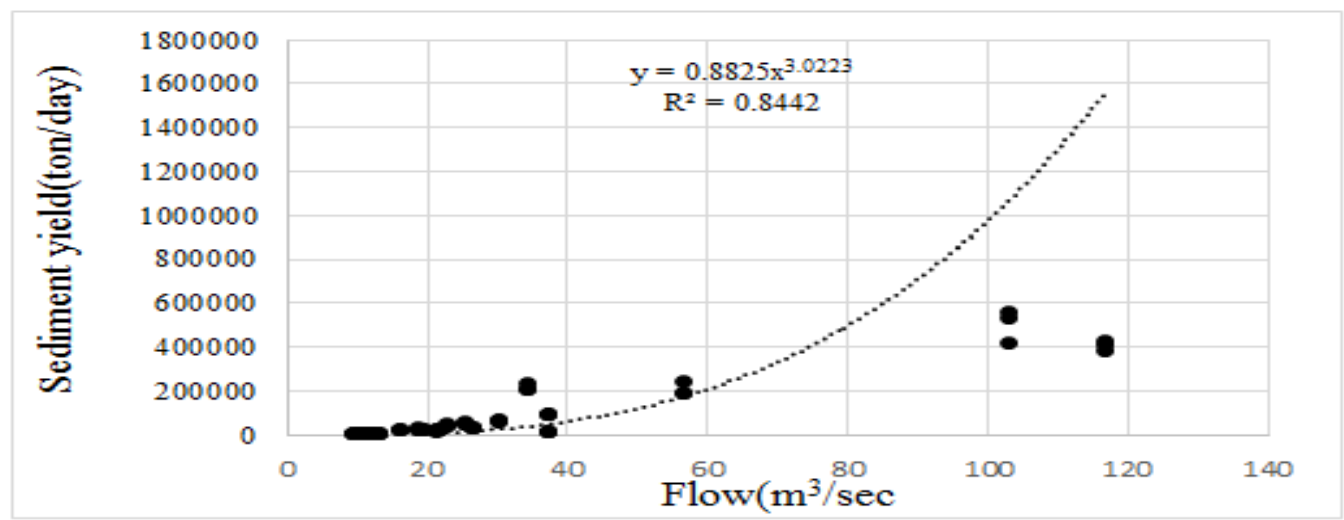

Figure 2.10: Sediment rating curve of AR at Melka Werer gauging

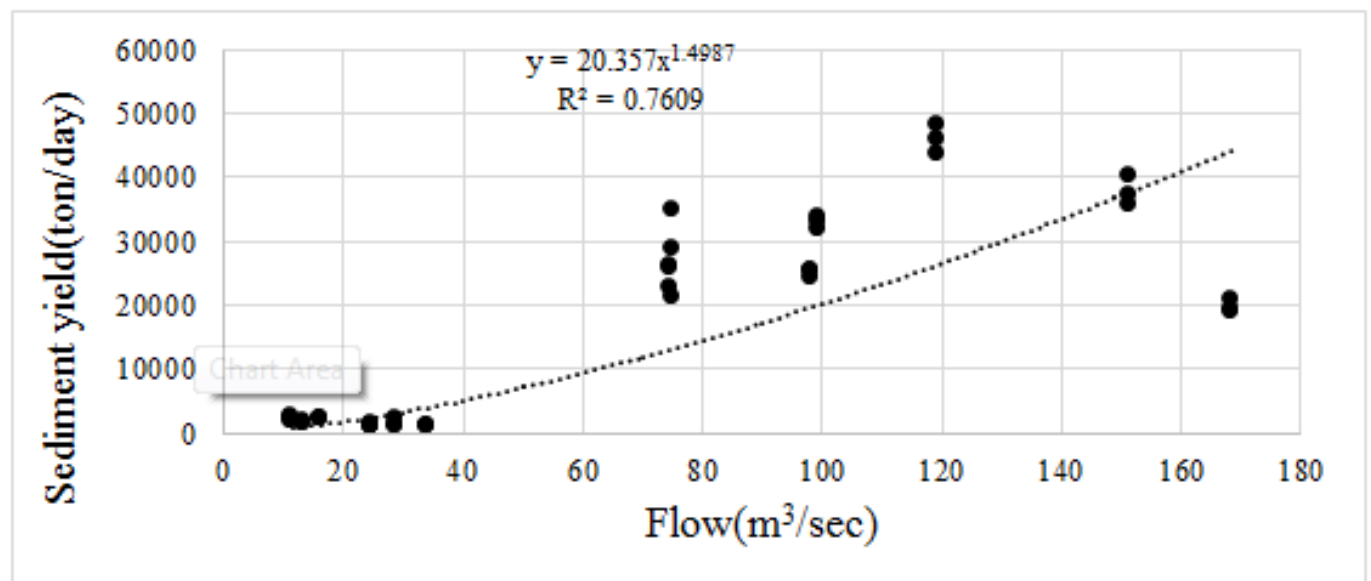

Figure 2.11: Sediment rating curve of AR at Tendaho gauging 


\section{SWAT Hydrological Model Results}

When the model run has completed and get ready for simulation, the area of the TDW was found to be $62,983 \mathrm{~km}^{2}$. The input land cover type was 13 and the soil type was 25 , but after the model run, they became 11 and 22, respectively. This was because of HRU formation, which was ordered by $10 \%$ land use and $10 \%$ soil type as the suggestion forwarded in SWAT user guide, as well as the threshold area limit was taken about $40 \%$ of the default value. This means that land use and soil types less than $10 \%$ have been merged to the nearer land use and soil types to make unique HRU.

The watershed has been divided into 79 sub-basins with a threshold area of 60,000 ha and 541 HRU based on the above mentioned threshold area and land use and soil type combinations. Then, the SWAT model simulation was performed on the whole TDW for both stream flow and sediment yield data sets.

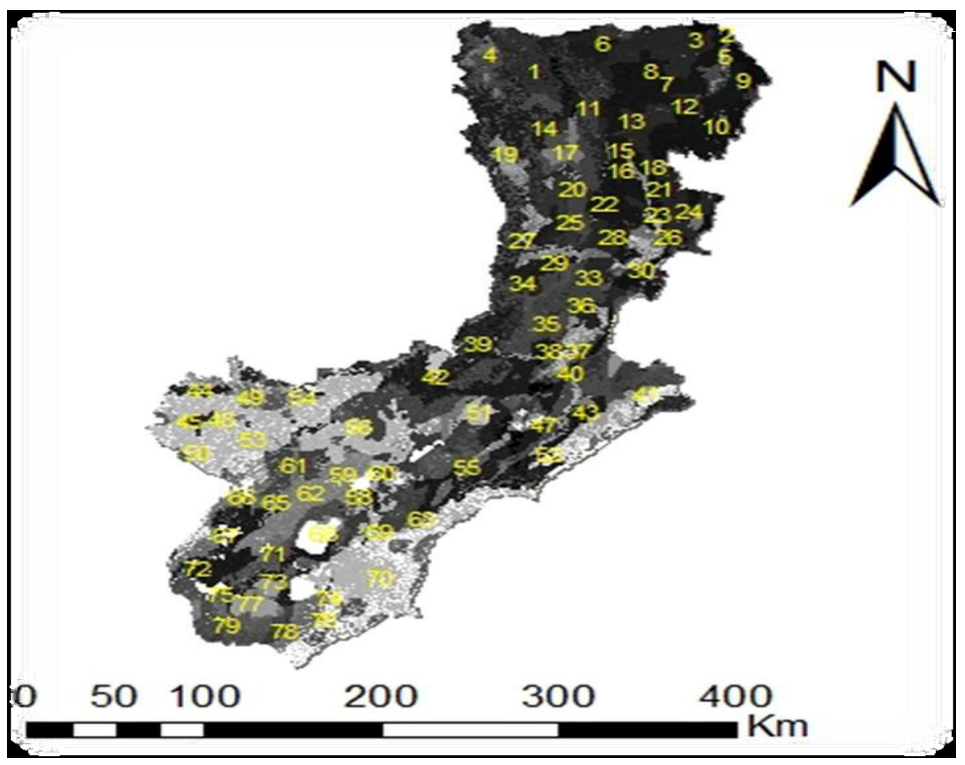

Figure 3.1: Delineated watershed, land use and soil map, overlay

\section{Sensitivity Analysis}

Sensitivity analysis for flow and sediment on this watershed was done in AR at Wonji, Melka Werer and Tendaho. Sensitivity analysis for stream flow at the three sites of calibration with 270 iterations each has given an output of 26 sensitive parameters with different degree of sensitivity. From these 26 parameters, only the first 7 parameters which were ranked from very high to low sensitivity class affected the simulated result when changed. The soil available water capacity which controls the surface runoff in the watershed was found to be the most sensitive of all. Other parameters like the base flow, depth from soil surface to bottom layer and the saturated hydraulic conductivity also influence the surface runoff of the watershed (Table 3.1).

\section{Flow Calibration}

After identifying sensitive parameters, calibration of the model at 
the selected stations was done manually. Till the best match of the simulated result and its corresponding observed flow has attained (Fig. 3.2-3.4), changing parameters has continued within the allowable ranges recommended by SWAT model developers. During efficiency computation, the first two years of simulation result was excluded, because this was used for model priming. Hence, the effect of the initial conditions such as soil water content was minimized. The ranges of the selected parameters for calibration are as stated in Table 3.1.

Table 3.1: Parameters set before and after calibration of SWAT for stream flow

\begin{tabular}{llll}
\hline $\begin{array}{l}\text { SWAT } \\
\text { Parameter }\end{array}$ & $\begin{array}{l}\text { Recommended range by sensitivity } \\
\text { analysis }\end{array}$ & $\begin{array}{l}\text { Initial } \\
\text { value }\end{array}$ & $\begin{array}{l}\text { Calibrated } \\
\text { value }\end{array}$ \\
\hline Sol-Awc & $\pm 25 \%$ & $* *$ & $-20 \%$ \\
Sol-Z & $\pm 25 \%$ & $* *$ & $-18 \%$ \\
Sol-K & $\pm 25 \%$ & $* *$ & $-24 \%$ \\
\hline
\end{tabular}

Then, the monthly calibrated graphical results of the three stations are Fig. 3.2, $3.3 \& 3.4$

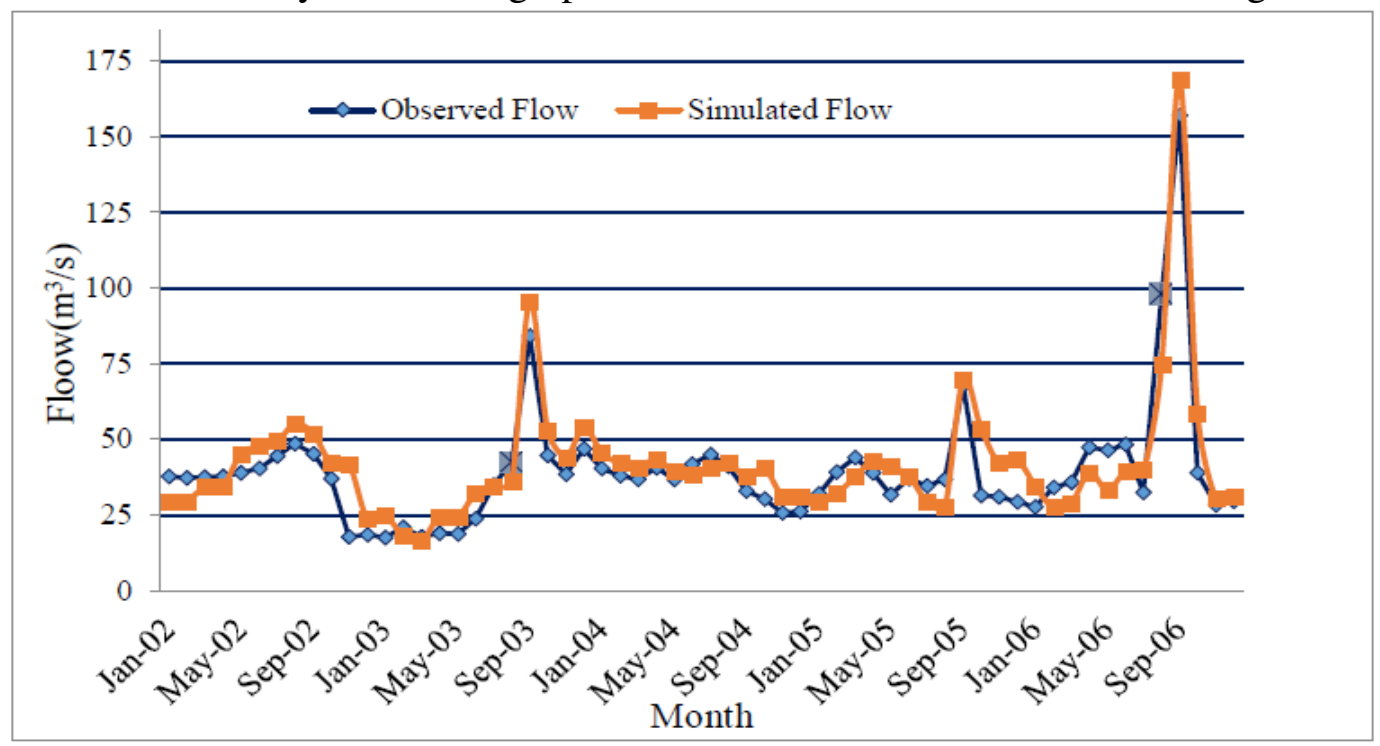

Figure 3.2: Simulated Vs. measured stream flow comparison at Wonji during calibration 


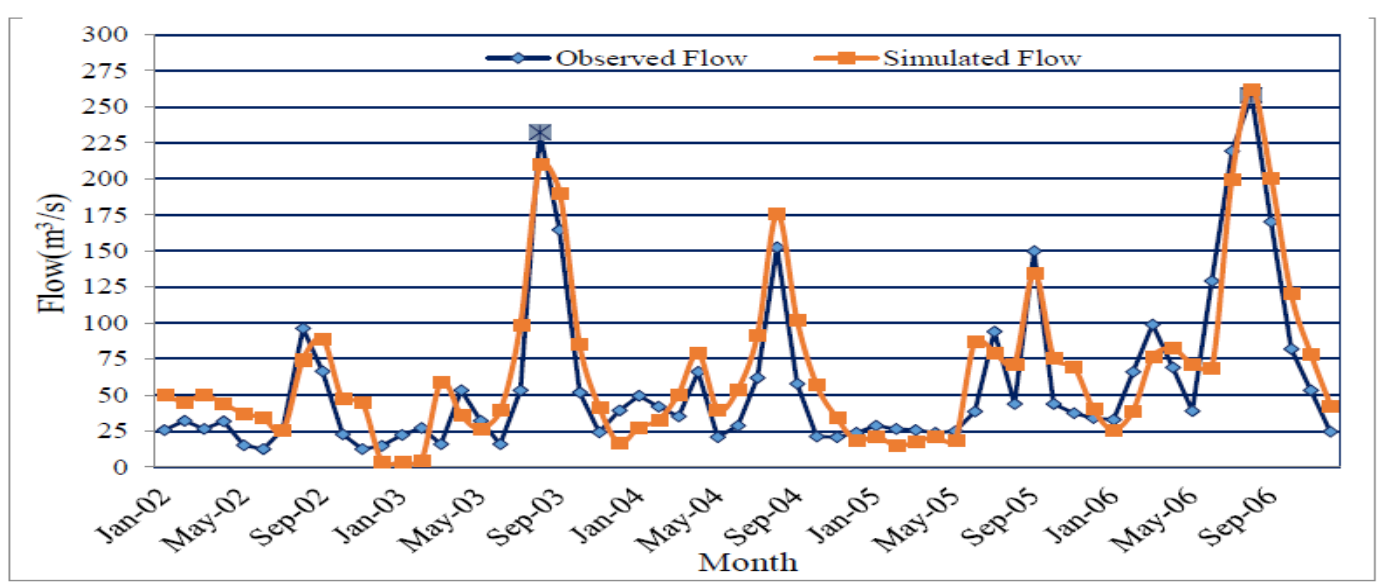

Figure 3.3: Simulated Vs. measured stream flow comparison at Melka Werer during calibration

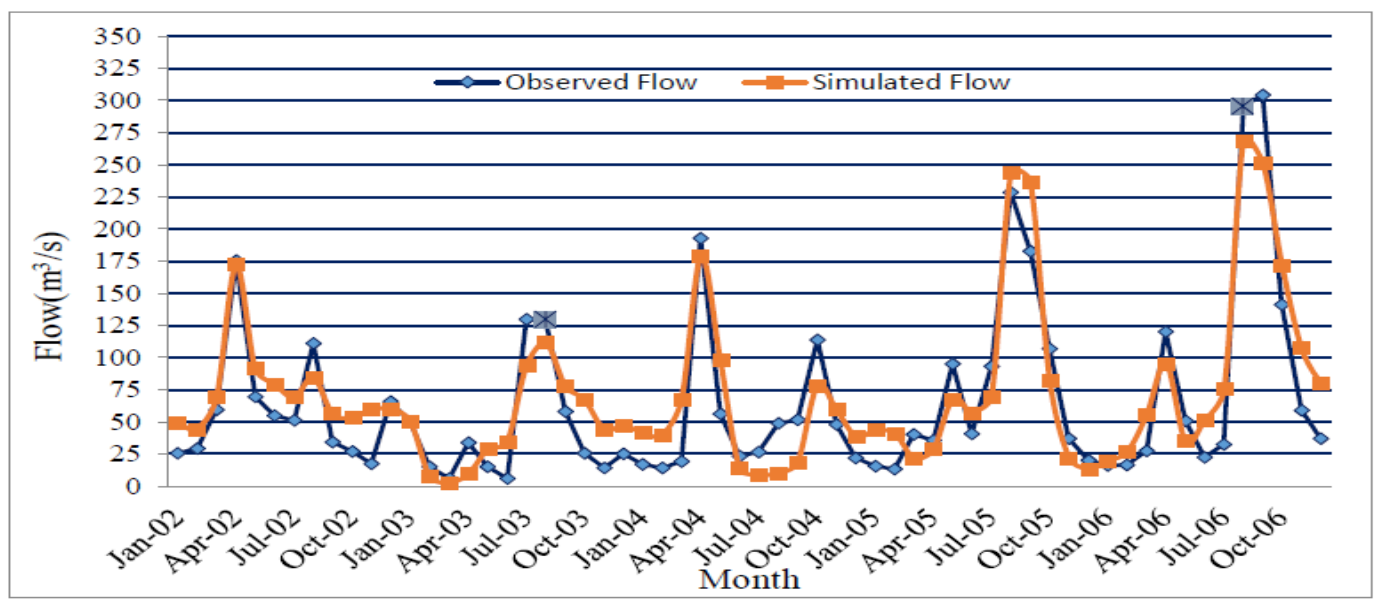

Figure 3.4: Simulated Vs. measured stream flow comparison at Tendaho during calibration

As the above graphs indicate, the monthly simulated and measured stream flows were correlated well with $\mathrm{R}^{2}$, ENS and PBIAS values of $0.84,0.82$ and 10.60 at Wonji, $0.83,0.80$ and -13.20 at Melka Werer and 0.84, 0.83 and -12.80 at Tendaho stations, respectively, which implies that the SWAT model has performed well at TDW on a monthly basis. The good fit of the model performance was evaluated as per the statistical efficiency indicator of Nash Sutcliffe value above satisfactory result (R2 > 0.60 and ENS > 0.50), as well as the percent bias (PBIAS) were between 10 and -15 in all stations. The regression analysis between the simulated and observed stream flow also show a good relation as shown in Figures 3.5, 3.6 and 3.7. 
Sediment Inflow Estimation and Mapping its Spatial Distribution.................ASMELASH et al.

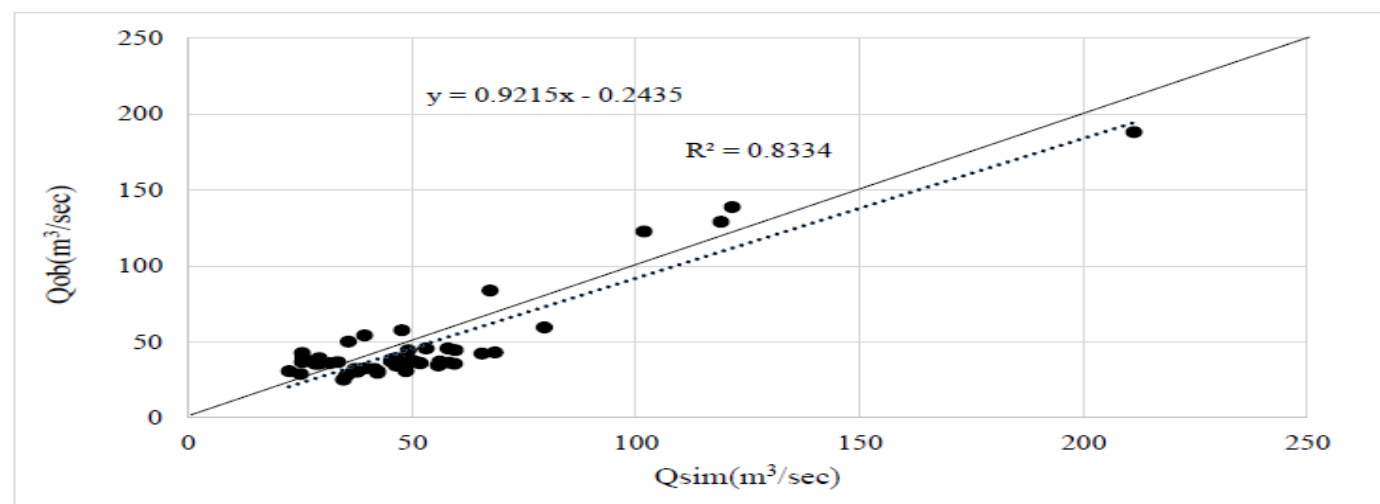

Figure 3.5: Regression analysis line and 1:1 Fit line of measured versus simulated flow at Wonji

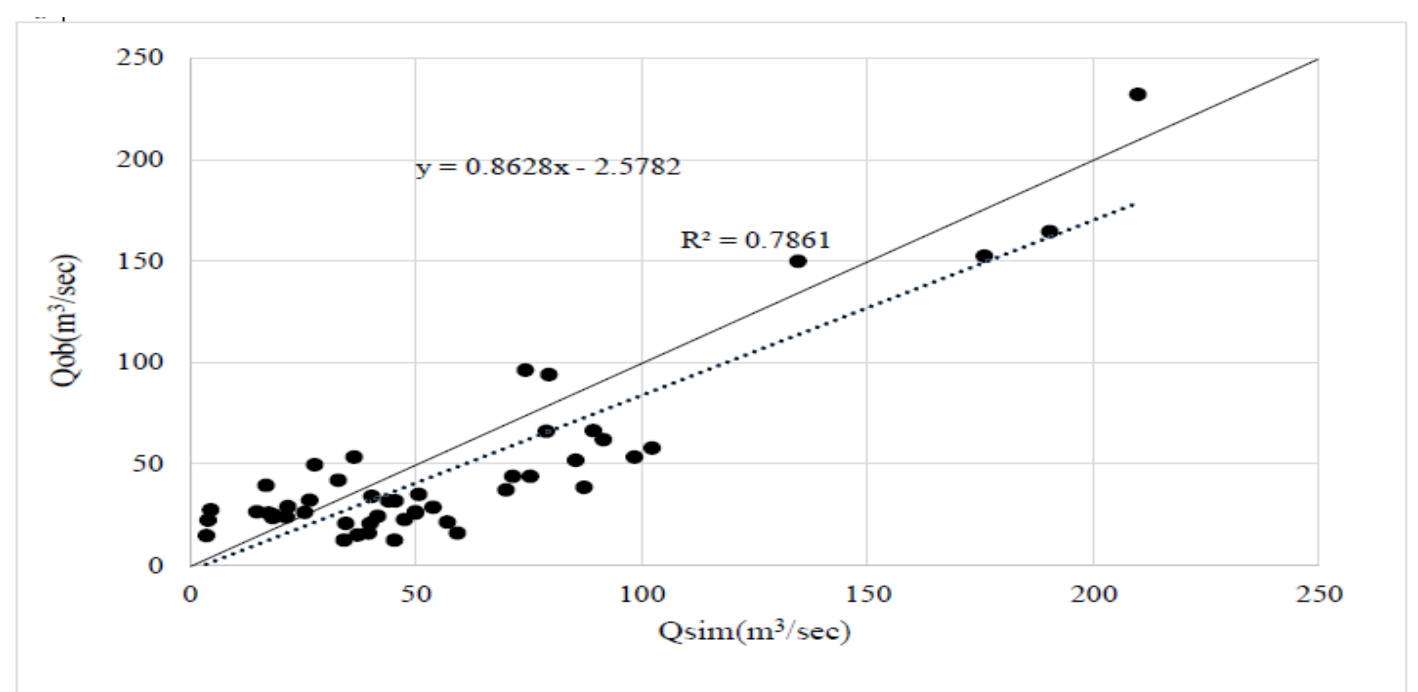

Figure 3.6: Regression analysis line \&1:1 Fit line of measured vs. simulated flow at Melka-Werer 


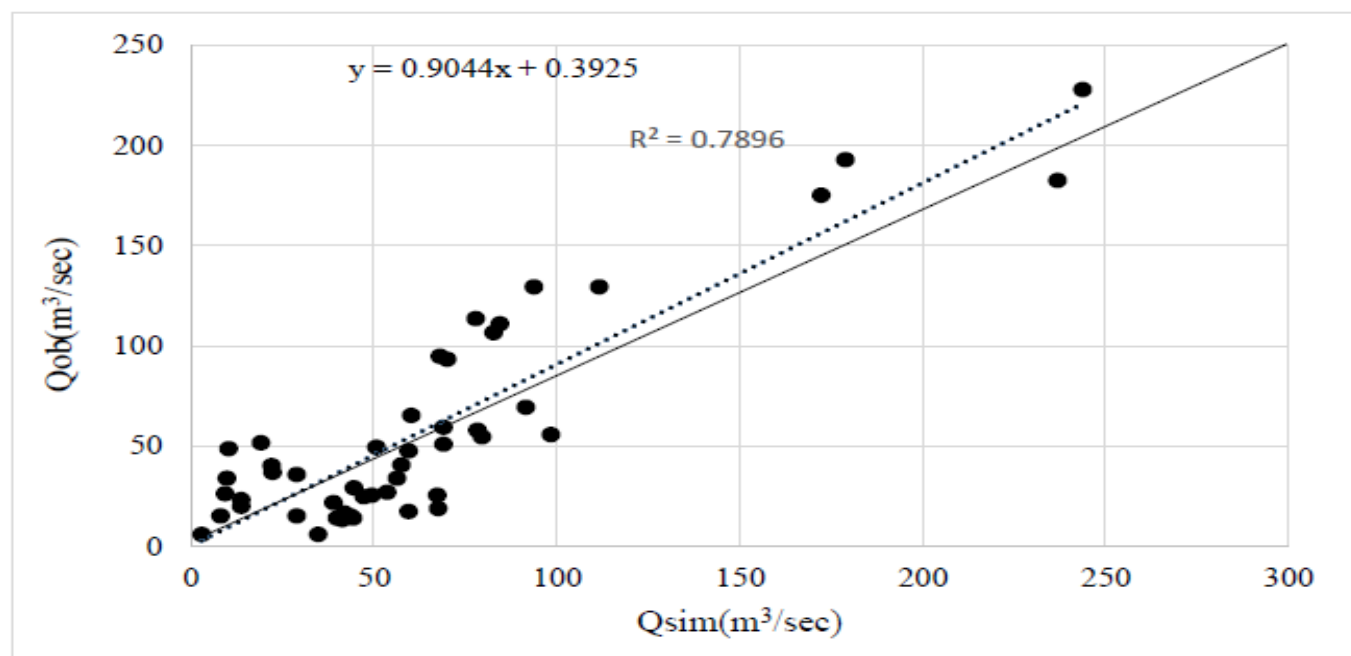

Figure 3.7: Regression analysis line \& 1:1 Fit line of measured vs. simulated flow at Tendaho

\section{Flow Validation}

Model validation was done at the same stations as calibration. The model simulation result was a good prediction of the measured flow data on the validation time period in all stations (Fig. 3.8, 3.9 and 3.10). The good fit of the model performance values $\left(\mathrm{R}^{2}\right.$, ENS and PBIAS) were $0.83,0.80$ and -10.40 at Wonji, $0.79,0.77$ and -11.70 at Melka Werer and $0.83,0.82$ and -12.85 at Tendaho stations, respectively, which were above satisfactory in all of the three stations.

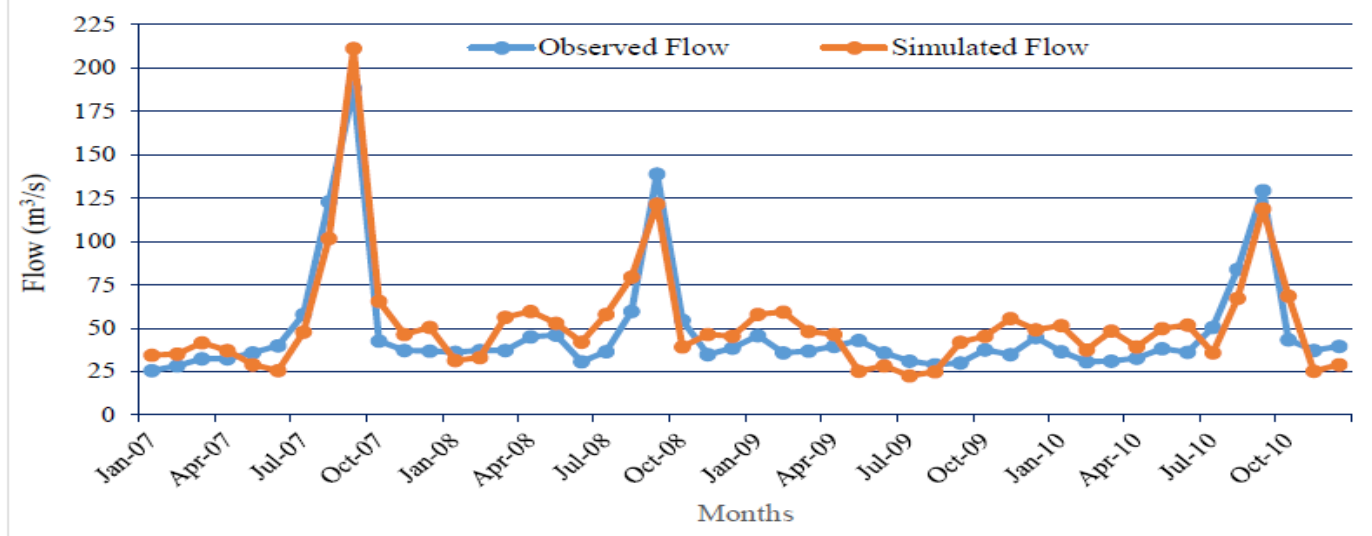

Figure 3.8: Graphical comparison of measured and simulated flow at Wonji 
Sediment Inflow Estimation and Mapping its Spatial Distribution.................ASMELASH et al.

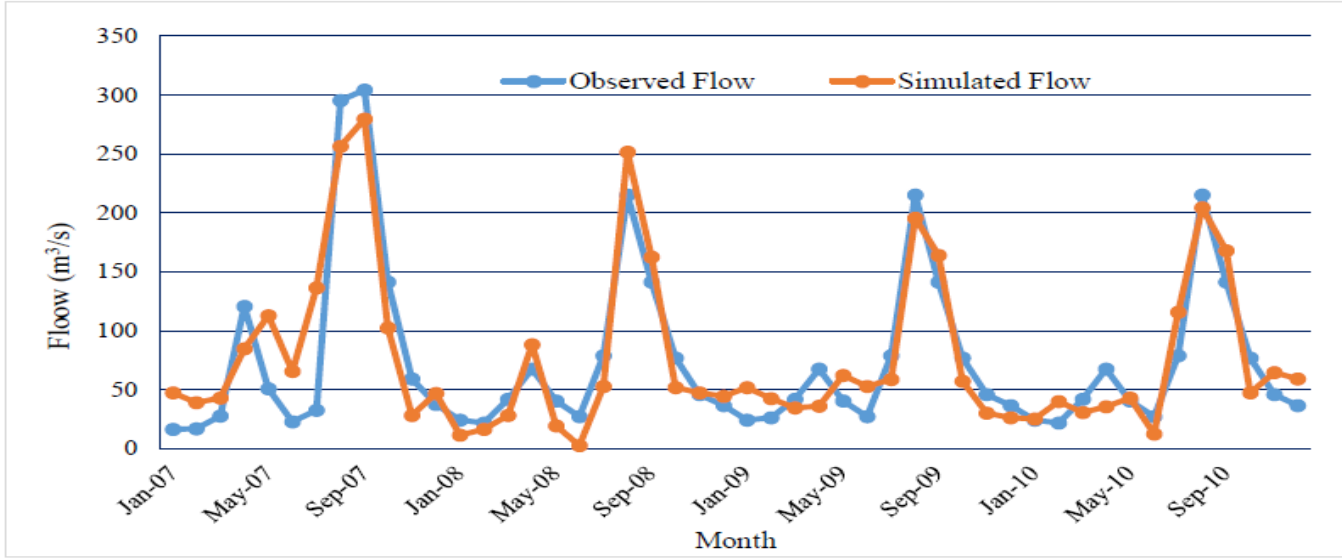

Figure 3.9: Graphical comparison of measured \& simulated flow at Melka Werer

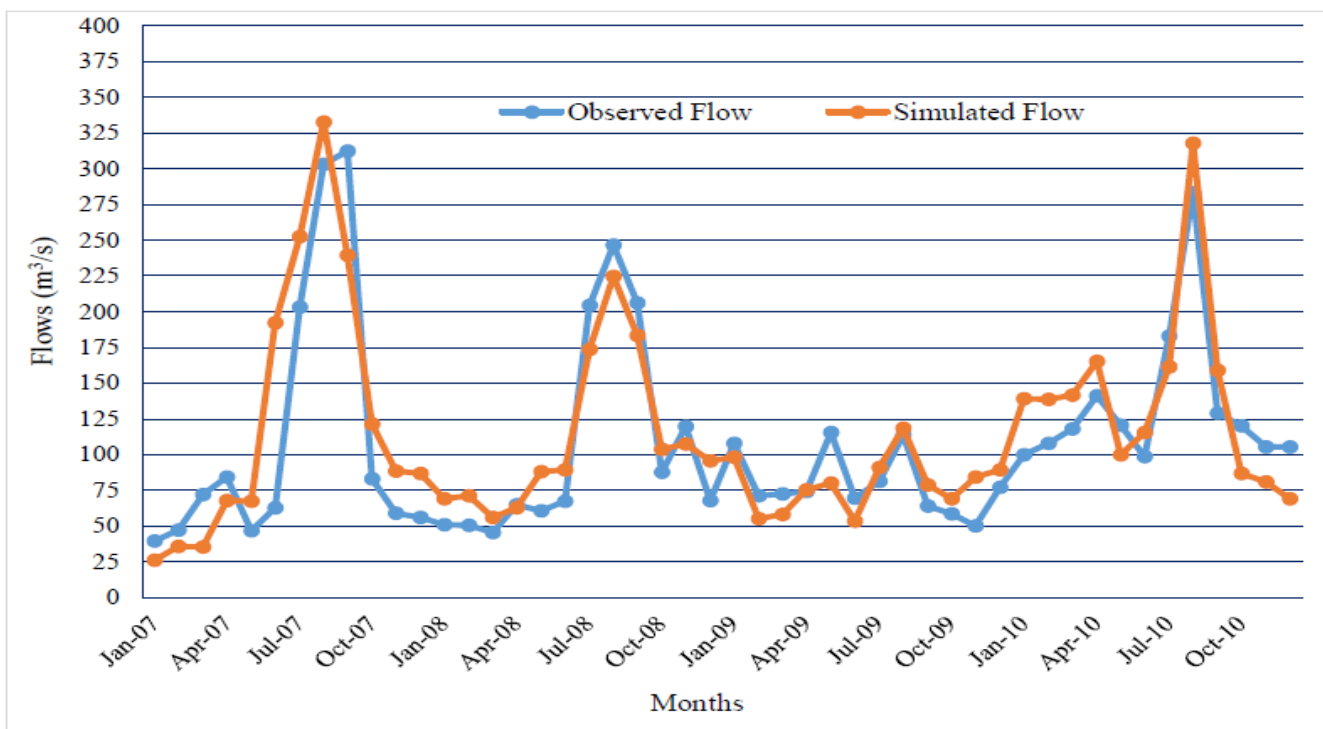

Figure 3.10: Graphical comparison of measured and simulated flow at Tendaho

\section{Sediment Calibration and Validation}

The SWAT calibration for sediment yield was done after the model has been validated for stream flow. SWAT model was calibrated for sediment by comparing the model simulated sediment yield with the measured sediment data at the three stations on a monthly basis. The reliability of the data for sediment yield calibration was not convincing, because from few scattered daily sediment data a sediment rating curve was developed and then a monthly sediment yield for the whole period of calibration and validation has been generated, but the $\mathrm{R}^{2}$ value was within the acceptable range. After sensitivity analysis has been done, seven parameters were identified, among these parameters only 3 of them were relatively highly sensitive, ranked from very high to high. The parameters with default and adjusted values are given in Table 3.2. Finally, the graphical comparisons of measured and simulated sediment yields 
Ethiopian Journal of Environmental Studies and Management Vol. 10 no.3 2017

at the three stations are displayed in Figures 3.11-3.13.

Table 3.2: Sensitive parameters, default values $\&$ their adjustment for sediment calibration

\begin{tabular}{llllllll}
\hline $\begin{array}{l}\text { Sensitivity } \\
\text { rank }\end{array}$ & Parameter & Description & $\begin{array}{l}\text { Relative } \\
\text { mean }\end{array}$ & $\begin{array}{l}\text { Range } \\
\text { bound }\end{array}$ & $\begin{array}{l}\text { Initial } \\
\text { value }\end{array}$ & $\begin{array}{l}\text { Adjusted } \\
\text { value }\end{array}$ & $\begin{array}{l}\text { Sensitivity } \\
\text { class }\end{array}$ \\
\hline $\mathbf{1}$ & Usle_P & $\begin{array}{l}\text { Usle support } \\
\text { practice factor }\end{array}$ & 2.37 & $1.0-0.0$ & 1.0 & 0.40 & Very high \\
$\mathbf{2}$ & Spcon & $\begin{array}{l}\text { Linear factor } \\
\text { for channel } \\
\text { sediment } \\
\text { routing }\end{array}$ & 1.71 & $\begin{array}{l}0.01- \\
0.0\end{array}$ & 0.001 & 0.001 & Very high \\
& & & & & & \\
$\mathbf{3}$ & Spexp & $\begin{array}{l}\text { Exponential } \\
\text { factor for } \\
\text { channel } \\
\text { sediment }\end{array}$ & 0.114 & $2.0-1.0$ & 1.0 & 1.55 & high \\
& & & & & & \\
& & & & & & \\
\hline
\end{tabular}

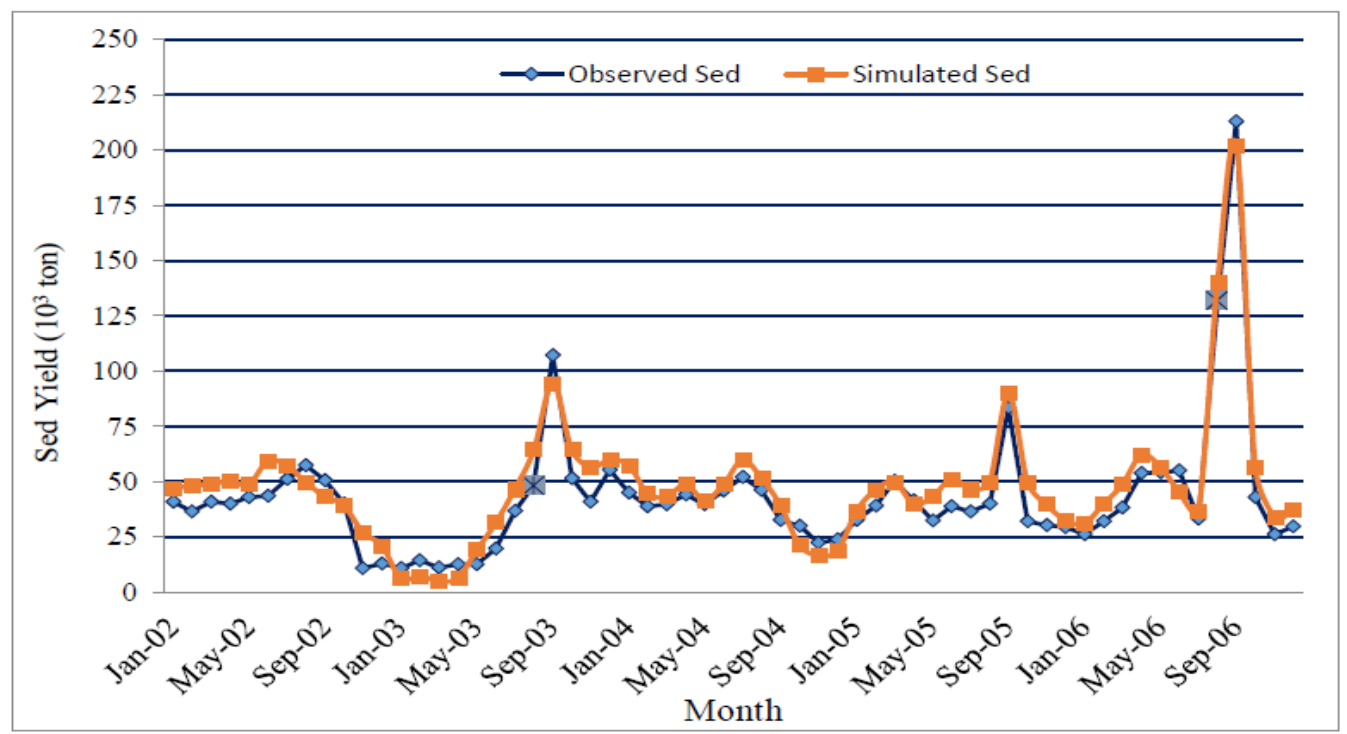

Figure 3.11: Graphical comparison of measured \& simulated sediment yield at Wonji during calibration 


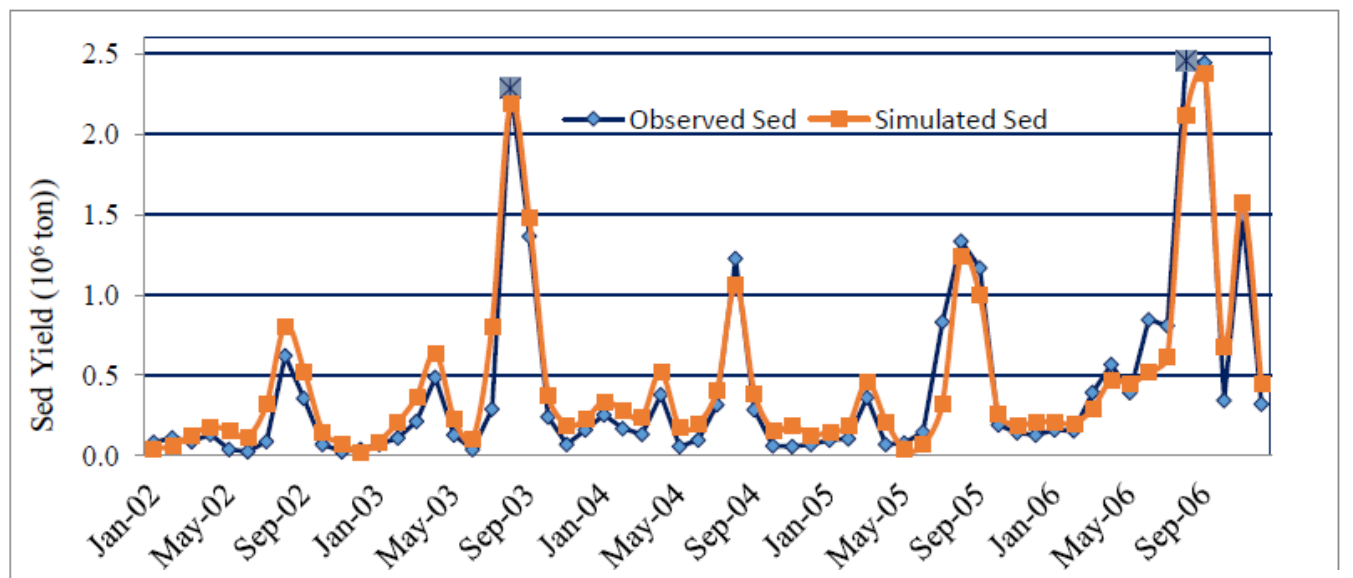

Sediment Inflow Estimation and Mapping its Spatial Distribution.................ASMELASH et al.

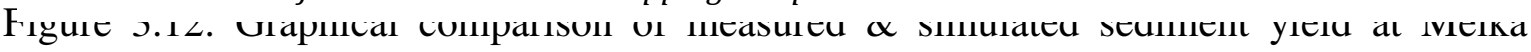
Werer during calibration

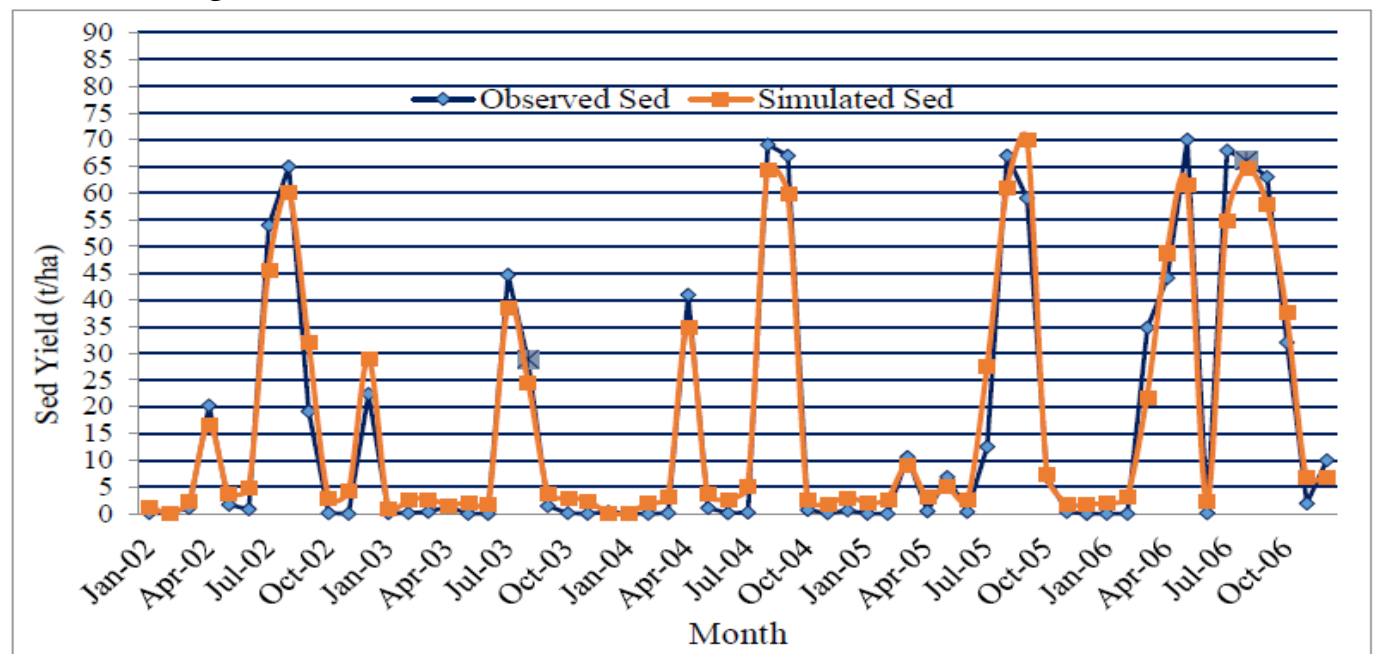

Figure 3.13: Graphical comparison of measured \& simulated sediment yield at Tendaho during calibration

After calibration, the model efficiency criteria was checked at the three sites of calibration and the simulated and derived sediment was compatible with coefficient of determination $\mathrm{R}^{2}$, ENS and PBIAS
(Table 3.3). Then, SWAT model was checked and verified for monthly simulated sediment yield at their corresponding calibrated sites (Fig. 3.143.19).

Table 3.3: SWAT model calibration and validation statistics for monthly sediment yield 


\begin{tabular}{llllll}
\hline Station & Simulation for & Simulation period & \multicolumn{3}{l}{ Monthly average efficiency } \\
\cline { 4 - 6 } Wonji & Calibration & $2002-2006$ & 0.88 & 0.86 & -11.20 \\
& Validation & $2006-2010$ & 0.93 & 0.89 & -10.72 \\
Melka Werer & Calibration & $2002-2006$ & 0.89 & 0.85 & -10.50 \\
& Validation & $2006-2010$ & 0.82 & 0.81 & -12.80
\end{tabular}

Ethiopian Journal of Environmental Studies and Management Vol. 10 no.3 2017

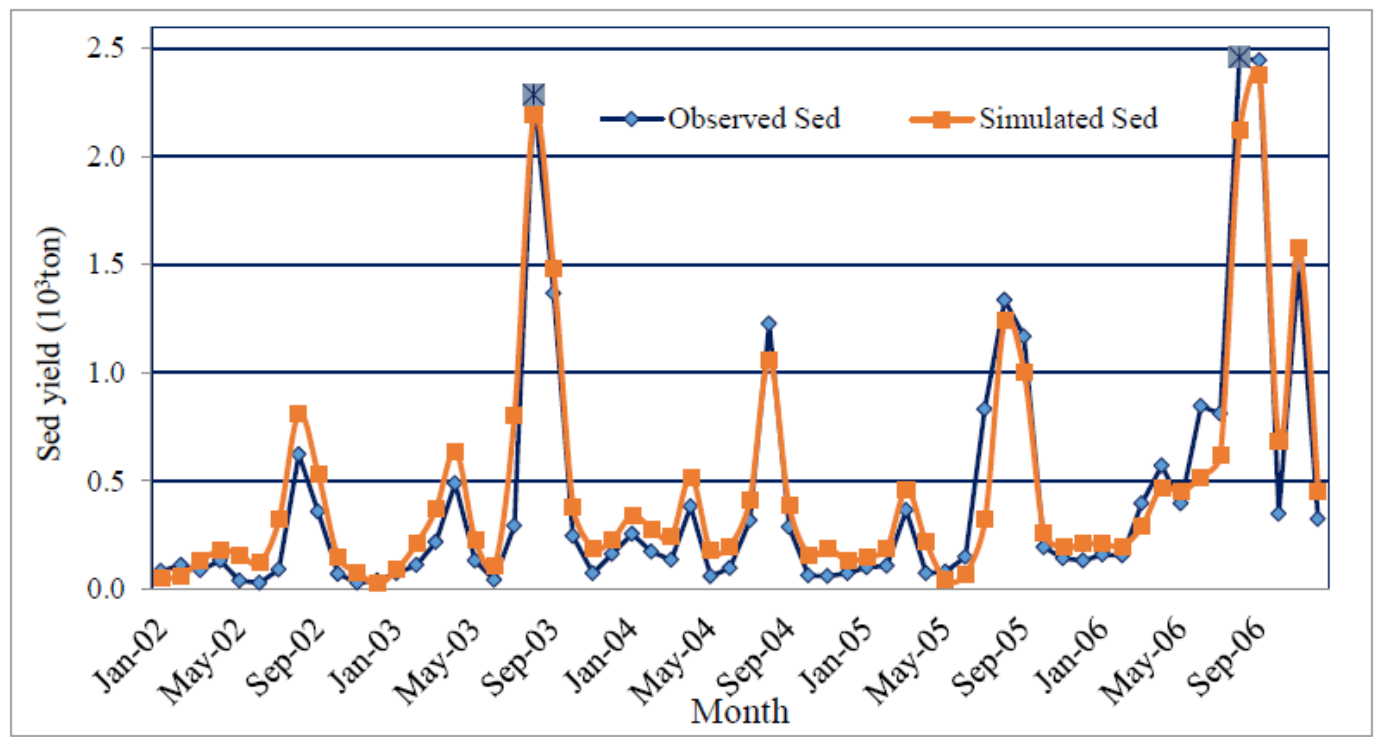

Figure 3.14: Graphical comparison of measured \& simulated sediment yield at Wonji during validation

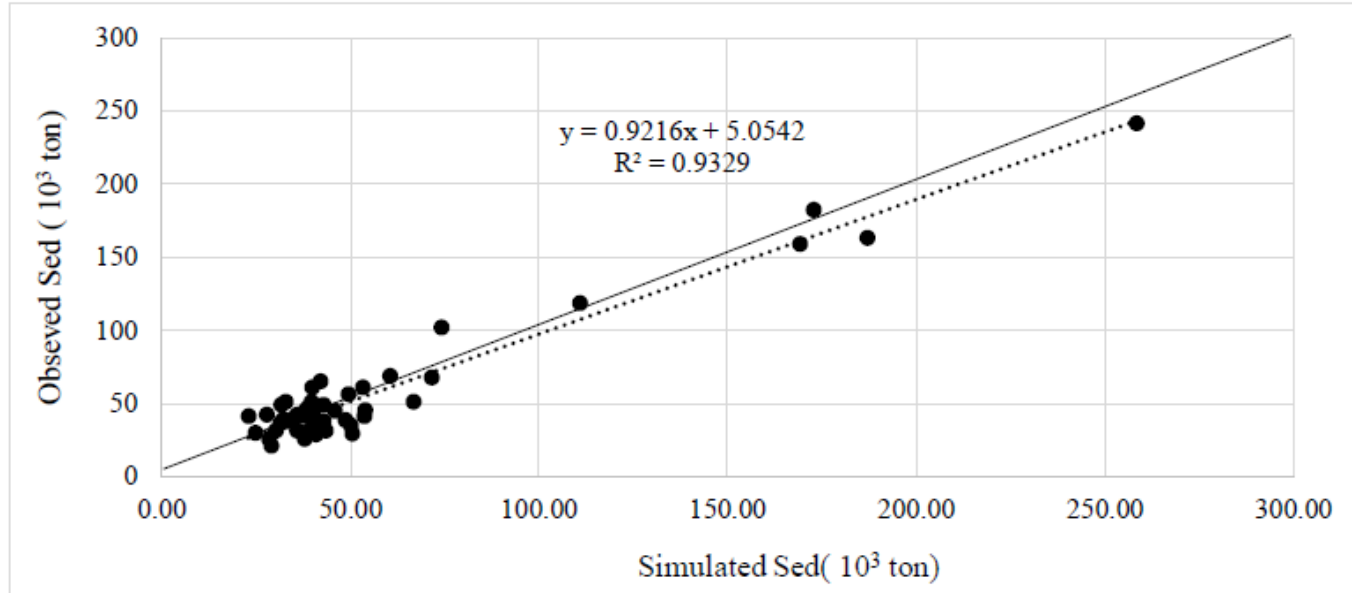

Figure 3.15: Regression analysis \& 1:1 Fit line of measured vs. simulated sediment yield at Wonji 
Sediment Inflow Estimation and Mapping its Spatial Distribution................ASMELASH et al.

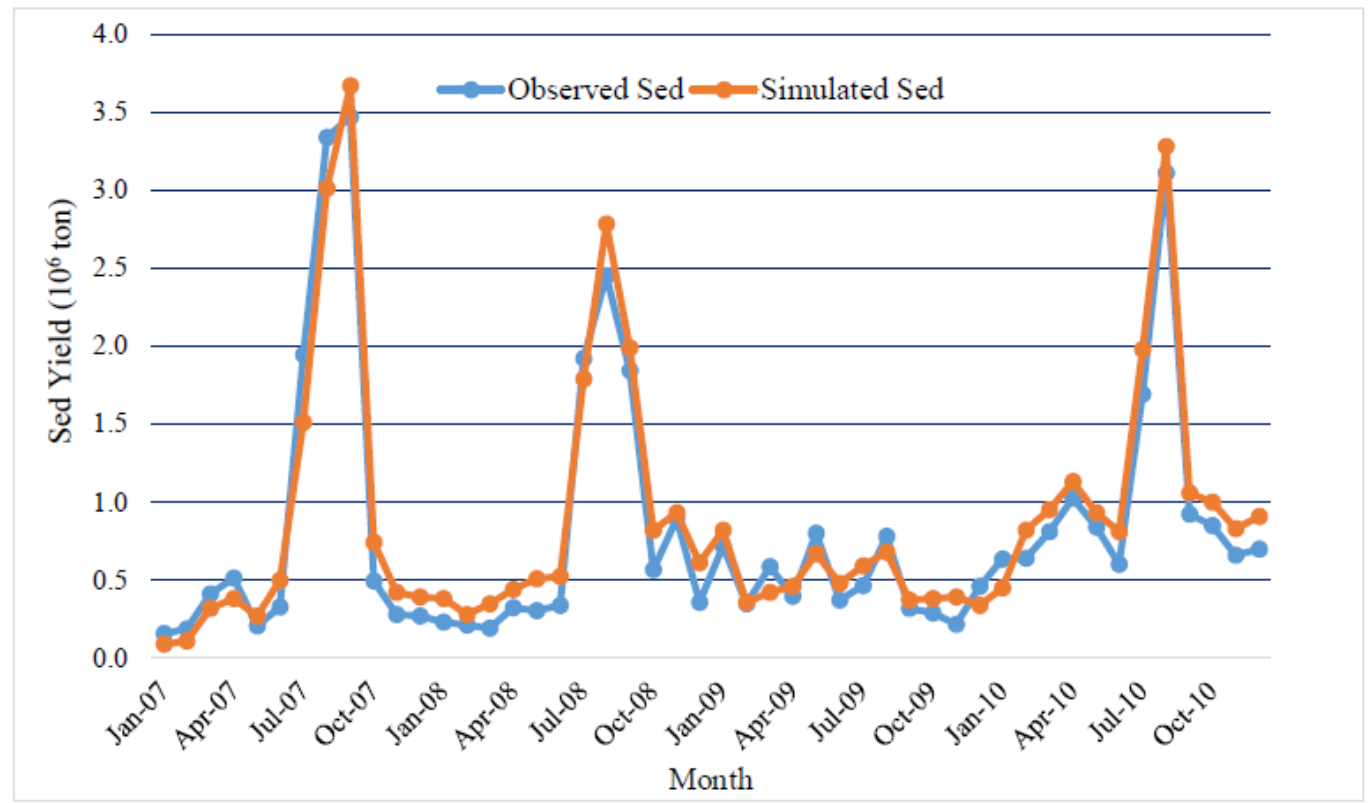

Figure 3.16: Graphical comparison of measured \& simulated sediment yield at Melka Werer during validation

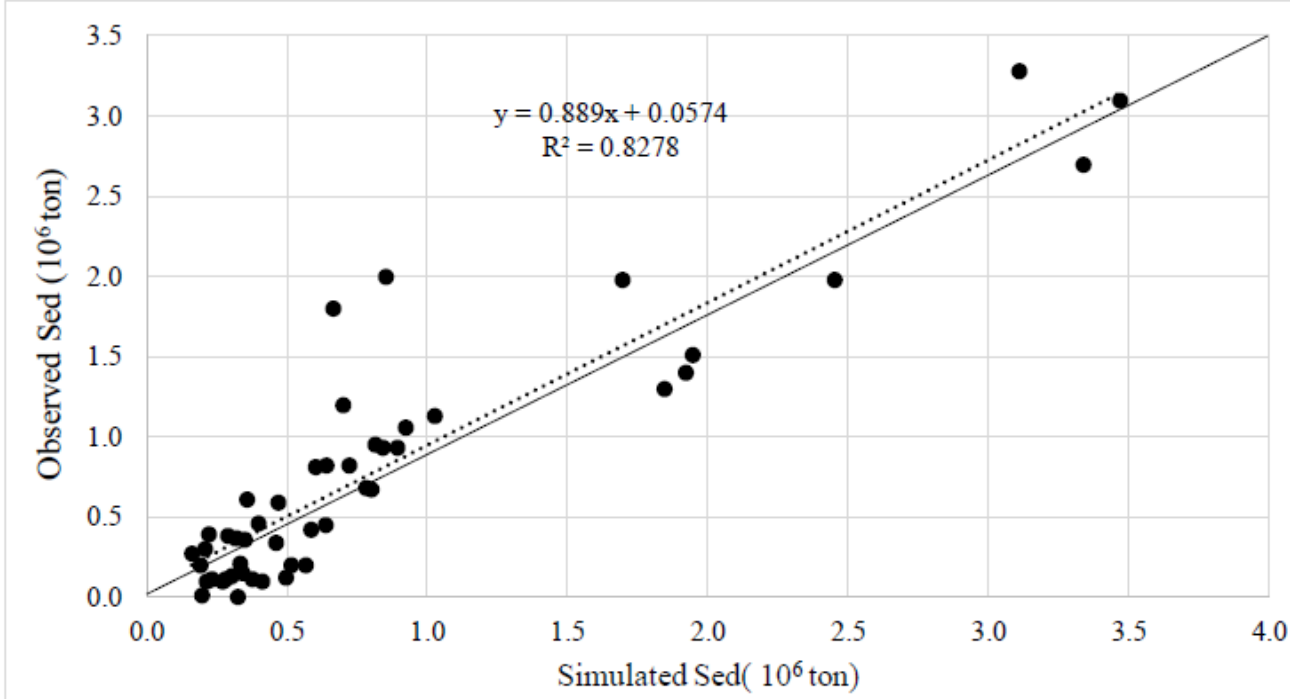

Figure 3.17: Regression analysis \& 1:1 Fit line of measured vs. simulated sediment yield at Melka Werer 


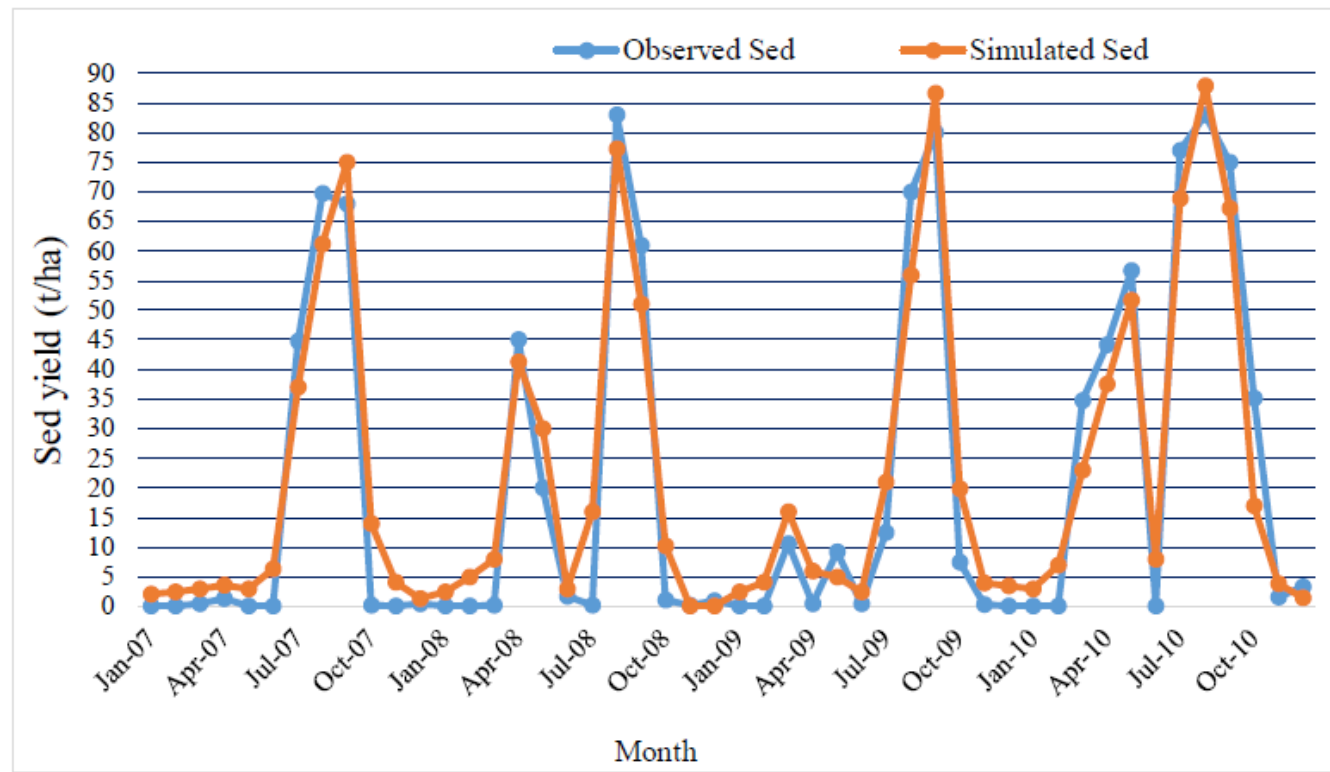

Figure 3.18: Graphical comparison of measured \& simulated sediment yield at Tendaho during validation

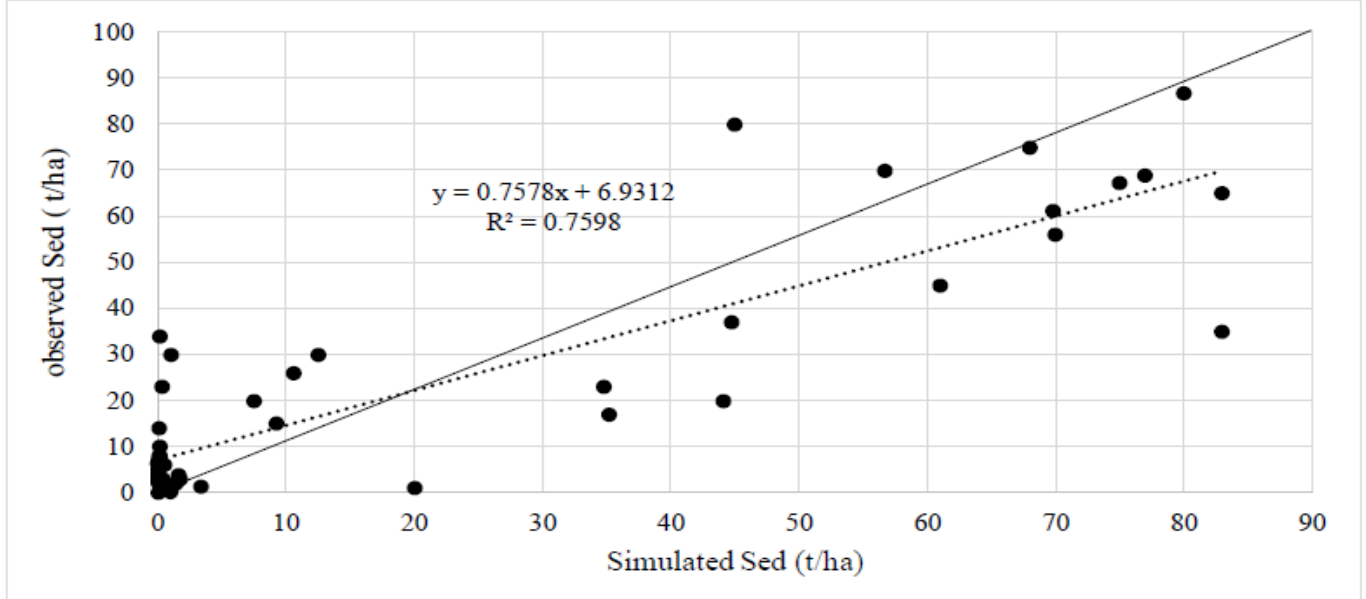

Figure 3.19: Regression analysis \&1:1 Fit line of measured vs. simulated sediment yield at Tendaho

From the sediment calibration and validation results at the selected sites, it was possible to generalize the model output for other sub-basins in the watershed at which the simulation was done, since SWAT is a distributed model and can predict the same result in the calibration region for the similar HRUs. Hence, the average annual sediment yield of TDW was found to be about 5.34 ton/ha/yr. Out of which, 59.08 million ton/yr reaches at Tendaho dam reservoir, implying there are hot spot areas of erosion contributing to this final sedimentation. Thus, TDW was partitioned into three sub-watersheds (Table 3.4), for simplicity of the analysis. 
Sediment Inflow Estimation and Mapping its Spatial Distribution.................ASMELASH et al.

Table 3.4: Erosion rate from sub-watersheds for downstream delivery

\begin{tabular}{lllrl}
\hline $\begin{array}{l}\text { Sub- } \\
\text { watershed }\end{array}$ & $\begin{array}{l}\text { Sub-basin } \\
\text { No. }\end{array}$ & $\begin{array}{l}\text { Erosion rate } \\
(\mathrm{t} / \mathrm{ha} / \mathrm{yr} .)\end{array}$ & $\%$ & Remark \\
\hline Wonji & 60 & 3.58 & 34 & $\begin{array}{l}\text { Delivered to Melka Werer } \\
\text { watershed }\end{array}$ \\
Melka Werer & 37 & 8.13 & 46 & $\begin{array}{l}\text { Delivered to Tendaho watershed } \\
\text { Dendaho }\end{array}$ \\
\hline
\end{tabular}

Note: the three watersheds are considered with no intersection

From Table 3.4, Melka Werer and Wonji sub-watersheds delivering $46 \%$ and $34 \%$ sediment yields to downstream, respectively, were found to be more affected by erosion, but it doesn't mean that Tendaho watershed was safe in regard to erosion at its sub-basins scale (Fig.3.20). The top three most severely eroded sub-basins of the whole watershed (Sub-basins 27, 34 and 29) were from Tendaho sub-watershed, and sub-basins with negligible eroded soil delivery rate (example, sub-basin 31, 21 and 5) also belong to Tendaho sub-watershed.

The sediment yield delivery rate of sub-basins to their consecutive downstream sub-basins depend on so many factors, such as shape of transporting streams, capability of transporting agent, existence of structures, etc. So, it is possible to say that streams and reservoirs at large are good sites for sediment deposition, if the force of the transporting agent (water) cease.

In the case of this study, the effect of Koka dam reservoir (sub-basin 57) was taken into consideration. The sediment outflow from this reservoir was about 11.2 million $\mathrm{t} / \mathrm{yr}$, even though 20.3 million $\mathrm{t} / \mathrm{yr}$ amount of sediment has been discharged to this sub-basin of the reservoir; implying approximately 9.1 million $\mathrm{t} / \mathrm{yr}$ sediment is being deposited into the reservoir. This reservoir stands on the safe side of Tendaho dam project, though Koka reservoir needs an assessment for its future working condition.

The sediment yields or erosion rates of sub-basins of this study were different; this is due to the combined effect of factors such as land use, soil type and slope, etc. More than 46\% (27.2 million tones out of 59.06 million tons) of eroded soil of the TDW was from Melka Werer sub-watershed (Table 3.4).

As per the research conducted by Hurni (1983), the range of the tolerable soil loss level for the various agroclimatic zones of Ethiopia was found to be 2 to $18 \mathrm{t} / \mathrm{ha}$. But, the annual soil loss rate at some sub-basins of TDW was above this tolerable limit. In addition, based on the relative soil erosion and sediment delivery of the sub-basins of TDW and current risk of the Tendaho dam project, the authors have classified the sediment delivery of the sub-basins into four classes (Table 3.5), for quick mitigation and decline of the sediment yield at Tendaho dam reservoir. 
Table 3.5: Eroded soil delivery classes of sub-basins

\begin{tabular}{ll}
\hline Sediment yield interval (t/ha/yr.) & Erosion class \\
\hline Above 9.40 & Severely eroded \\
$4.50-9.40$ & Moderately eroded \\
$3.0-4.50$ & Acceptable erosion \\
Below 3.0 & Negligible erosion \\
\hline
\end{tabular}

The spatial location of the sediment yield classes of sub-basins based on the classification of Table 3.5 are mapped as shown in Figure 3.20.

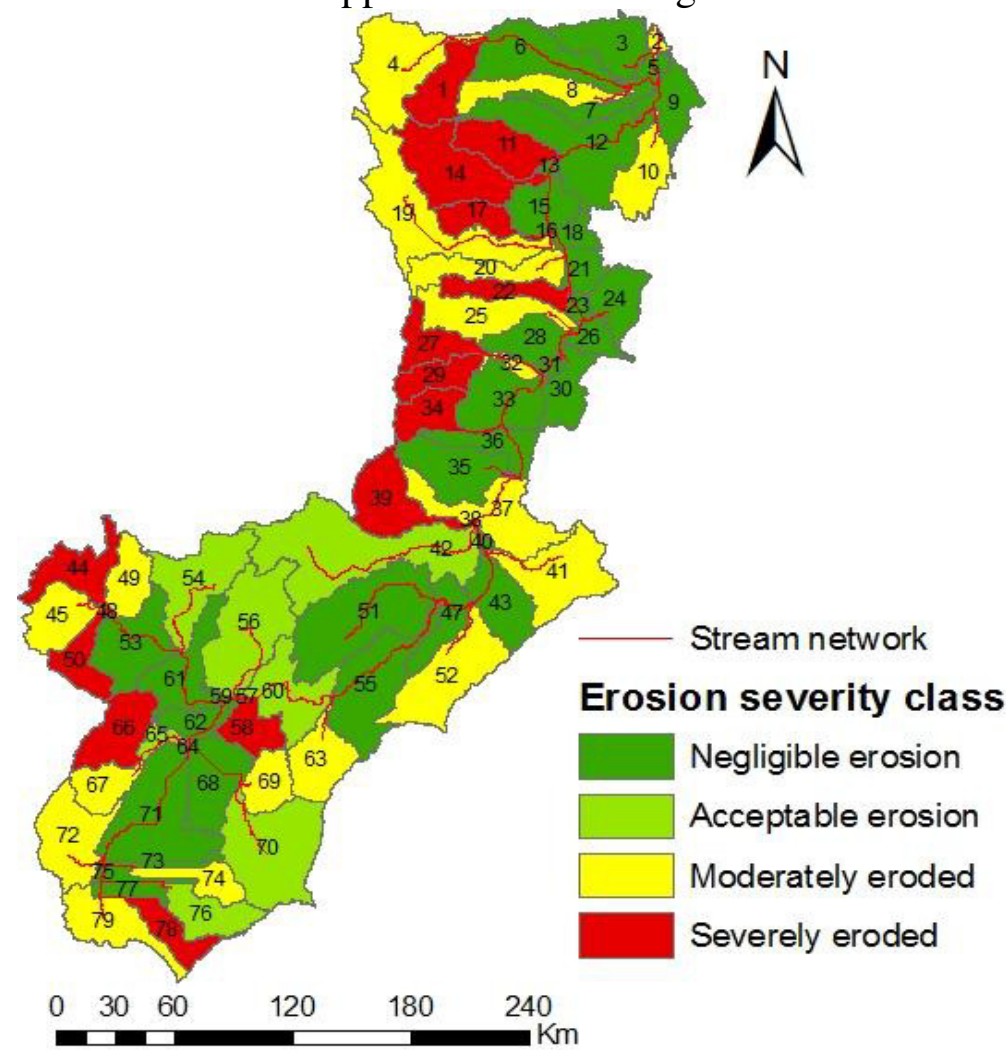

Figure 3.20: The sub-basin spatial distribution of sediment yield of TDW

The sediment yield from a given watershed is dominantly related to rainfall and runoff, soil erodibility, slope length and steepness, cropping and management of the soil, and any supporting practices implemented to prevent erosion (Dilnesaw and Bonn, 2006). 


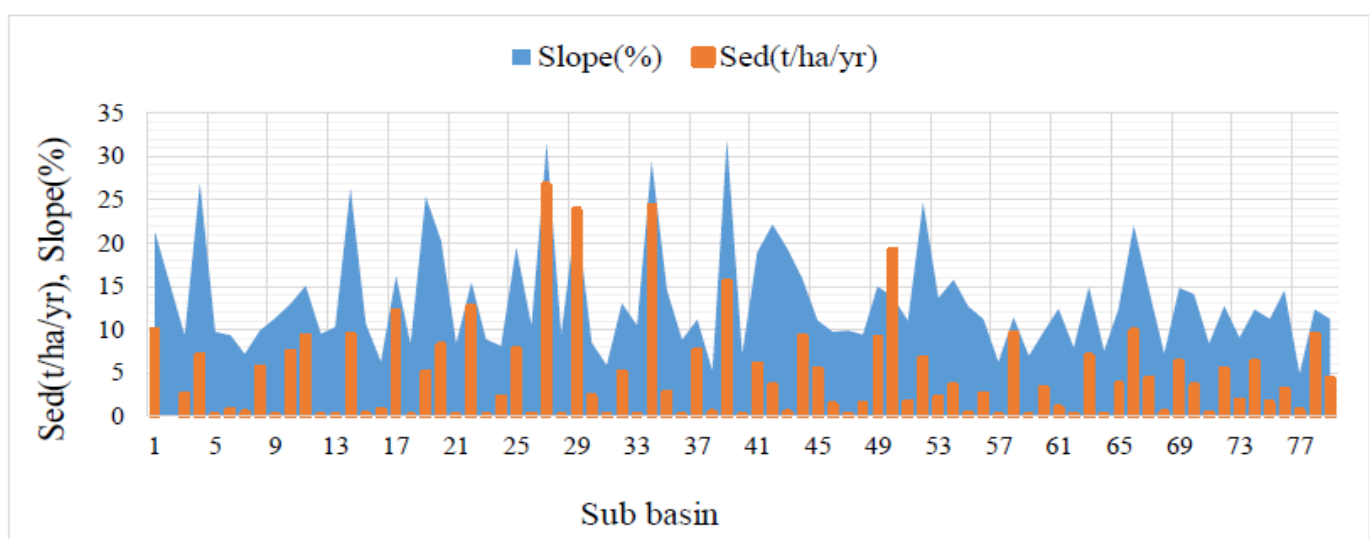

Figure 3.21: The graphical comparison of the effect of slope steepness on sediment yield

The sub-basins eroded severely have steep slope compared to the less eroded sub-basins (Figure 3.21). Sub-basins 27 and 34 are the first two severely affected by erosion which belongs to the second and third steepest sub-basins. While, subbasins 29 and 50 are not from the top four steepest sub-basins, even though, they are the third and fourth severely eroded sub-basins, implying the existence of other factors. The dominant land use of the highest sediment yielding subbasins (27 and 34) is range grasses, and soil type of leptosols and regosols, respectively. And, sub-basin 29 has a dominant land use of bushes with a dominant soil type of cambisols, but subbasin 50 has a dominant land use of agricultural land and soil type of vertisols. However, the dominant land use/cover and soil type in the least sediment yielding sub-basins were summer pasture and regosols, respectively, mixed with deciduous forests.

The SWAT based sediment yield of the TDW was compared with some of the related studies undertaken in Ethiopia (Fekadu, 2008; Engidayehu, 2014). The amount of annual sediment inflow into Tendaho reservoir was therefore found to be almost similar to what was found in these studies. However, another study supported by GIS simulation for soil loss rate analysis of the whole Awash basin using the universal soil loss equation by (Bizuwerk et al., 2003), showed a deviation from the output of this paper. This may be due to three rather simple reasons: The study by Bizuwerk et al. (2003) was a soil erosion, not sediment yield at a fixed spatial point; it was a GIS supported study, while this study was supported by a physically based and distributed SWAT model; and the watershed of this study was portion of the study by Bizuwerk et al. (2003).

\section{Conclusion}

In general, about $46 \%$ of the soil was eroded and delivered from Melka Werer sub-watershed. The sub-basins belonging to Melka Werer sub-watershed were found to deliver an annual eroded sediment yield ranging from $15.48 \mathrm{t} / \mathrm{ha}$ to $0.05 \mathrm{t} / \mathrm{ha}$ to the Tendaho sub-watershed. Similarly, Wonji sub-watershed was found to deliver $34 \%$ of the total sediment yield at Tendaho reservoir, ranging from $19.13 \mathrm{t} / \mathrm{ha}$ to $0.06 \mathrm{t} / \mathrm{ha}$ on annual average basis; while, the remaining is from the Tendaho subwatershed. 
Therefore, if the rate of sediment reaching at Tendaho reservoir continues this way, there is no doubt that the project will be in question. So, for the ease of focusing on the high sediment contributing sub-basins for mitigation, the sediment delivery rate of sub-basins are clearly quantified and mapped in this paper, implying sub-basins with the relatively higher sediment delivery rate were considered as the most severely eroded sub-basins and needs prior mitigation measures to make their downstream projects, such as Tendaho dam, safe.

\section{Recommendation}

According to the results;

1.It is recommended to develop scenarios of different sediment reduction methods, especially on the sub-basins of the watershed identified as severely eroded.

2.Malfunctioned hydro-meteorological stations are recommended to be maintained or replaced early and additional gauging stations for data accuracy are recommended in the area.

\section{References}

Alam, S. (2004), "Sedimentation management in hydro-reservoirs", Delhi, India.

Bizuwerk, A., Taddese, G. and Getahun, Y. (2003). "Application of GIS for Modeling Soil loss Rate in Awash River Basin", Ethiopia.

Dilnesaw, A. and Bonn, C. (2006). "Modelling of hydrology and soil erosion of upper Awash River Basin", PhD Thesis, university of Bonn: p.233.
Engidayehu, C. (2014). "SWAT based estimation of sediment yield from Guder watershed, Abbay Basin, Ethiopia", Master's thesis, Arbaminch University.

Fekadu F. (2008). "Establishing RainfallRunoff-Discharge Relationship in Blue Nile basin", Master's Thesis, Arbaminch University.

Hurni, H. (1983). "Degradation and conservation of the resources in the Ethiopian highlands", JSTOR, 123 130.

Lenhart, T., Eckhardt, K., Fohrer, N. and Frede, H.G. (2002). "Comparison of two Different Approaches of sensitivity analysis", Phys. Chem. Earth, 27: 645 - 654 .

Morris, M.D., Gregory, L., Fan, K.L. and Jiahua, J. (1998). "Reservoir Sedimentation Handbook", McGrawHill Book Co., New York.

Morris, M.D. (1991). "Factorial sampling plans for preliminary computational Experiments", Techno metrics 33(2): $161-174$.

Refsgaard, J.C. and Storm, B. (1996). "calibration and validation of hydrological models", Distributed Hydrological modelling (eds. M.B. Abbott and J.C. Refsgaard), Kluwer Academic publishers, 41 - 54 .

Water Works Design \& Supervision Enterprise (WWDSE) in association with Water and Power Consultancy Services (WPCS, India) (2005). "Hydrology of Tendaho Dam, Final Design Report, Addis Ababa, Ethiopia. Winchell, M. R., Srinivasan, R., Di Luzio, M. and Arnold, J. G. (2007). "Arc SWAT Interface for SWAT2005. Grassland, Soil \& Water Research Laboratory", USDA Agricultural Research Service, Temple, Texas. 